Review

\title{
The Lock is the Key: Development of Novel Drugs through Receptor Based Combinatorial Chemistry
}

\author{
Nikola Maraković and Goran Šinko* \\ Institute for Medical Research and Occupational Health, Ksaverska cesta 2, p.p. 291, HR-10001 Zagreb, Croatia \\ *Corresponding author: E-mail: gsinko@imi.hr
}

Received: 16-12-2016

\begin{abstract}
Modern drug discovery is mainly based on the de novo synthesis of a large number of compounds with a diversity of chemical functionalities. Though the introduction of combinatorial chemistry enabled the preparation of large libraries of compounds from so-called building blocks, the problem of successfully identifying leads remains. The introduction of a dynamic combinatorial chemistry method served as a step forward due to the involvement of biological macromolecular targets (receptors) in the synthesis of high affinity products. The major breakthrough was a synthetic method in which building blocks are irreversibly combined due to the presence of a receptor. Here we present various receptor-based combinatorial chemistry approaches. Huisgen's cycloaddition (1,3-dipolar cycloaddition of azides and alkynes) forms stabile 1,2,3-triazoles with very high receptor affinity that can reach femtomolar levels, as the case with acetylcholinesterase inhibitors shows. Huisgen's cycloaddition can be applied to various receptors including acetylcholinesterase, acetylcholine binding protein, carbonic anhydrase-II, serine/threonine-protein kinase and minor groove of DNA.
\end{abstract}

Keywords: Drug design; Dynamic combinatorial chemistry; Huisgen's cycloaddition; in situ click-chemistry; Receptor-accelerated synthesis; Receptor-assisted combinatorial chemistry

\section{Introduction}

The main focus of drug discovery is the identification of compounds that can modify molecular targets associated with certain diseases inducing a positive response. While natural products have inspired the design of most drugs in the past, the processes of lead discovery and optimization today rely on the preparation of large collections of new compounds, referred to as "libraries". Choosing large numbers of structurally diverse compounds is primarily governed by the complexity of natural products, which increases the difficulty, time, and cost of the preparation of such compounds. Also, as suggested by a computational study by Bohacek et al., the total number of "drug-like" compounds $(<30$ non-hydrogen atoms, < 500 Daltons; only $\mathrm{H}, \mathrm{C}, \mathrm{N}, \mathrm{O}, \mathrm{P}, \mathrm{S}, \mathrm{F}, \mathrm{Cl}$ and $\mathrm{Br}$; stable in the presence of water and oxygen) is as large as $10^{63}$ indicating that the vast majority of "drug-like" compounds are yet to be discovered. ${ }^{1}$ The introduction of combinatorial chemistry seemed to resolve the problem of preparing large libraries by focusing on building libraries of more complex compounds from simple building blocks. Building blocks are combined in a maximum number of possible combinations through independent synthesis. In the final step, each compound is independently tested for activity.

Independent testing of a large number of newly synthesized compounds significantly reduces the potential of conventional combinatorial methods. However, by the early 2000s, it became clear that conventional combinatorial chemistry turned out to be much less efficient than expected with only a few developed drugs reported and most industrial combinatorial chemistry libraries were disbanded. $^{2}$

In 1894, the German chemist Emil Fischer suggested a model of enzyme specificity by which an enzyme and its substrate possess specific complementary geometric shapes that fit exactly one into another like a lock and key. Although this model is more than 100 years old, E. Fischer's idea is still valid. Dixon and Villar showed that a protein can bind a set of structurally diverse molecules with similar affinities in the nanomolar range, whereas analogues closely related to one of the good binders show only weak affinities $(>2.5 \mathrm{mM}) .{ }^{3}$ Chemists created an approach where novel potentially bioactive compounds are not synthesized by pure statistical reorganization of joi- 
ning building blocks but forcing them in the right direction by including a macromolecular target (receptor) itself in this process. This was done through the introduction of a receptor-assisted combinatorial chemistry (RACC), sometimes also referred to as target-guided synthesis (TGS). ${ }^{4}$ In contrast to conventional combinatorial methods, in RACC the macromolecular target (protein or DNA) is directly involved in the choice of joining building blocks.

The concept of RACC can be divided into dynamic combinatorial chemistry (DCC) and receptor-accelerated synthesis (RAS), also called kinetically controlled TGS. In DCC, the reaction that joins the building blocks is reversible, whereas RAS uses only reactive building blocks joined irreversibly. The subset of RAS called in situ click chemistry, which uses the Huisgen's 1,3-dipolar cycloaddition of azides and alkynes (Huisgen's cycloaddition) to irreversibly join the building blocks, will be covered with special interest. ${ }^{5,6}$

\section{Dynamic Combinatorial Chemistry Method}

Dynamic combinatorial chemistry is a subset of RACC in which building blocks are joined through a reversible covalent reactions, generating a large equilibrium-controlled library of compounds referred to as a dynamic combinatorial library (DCL) ${ }^{7,8}$ The addition of biological targets during the generation of DCL stabilizes the library members with the highest affinity toward the biological target, moving the equilibrium toward high-affinity members. A comparison of the composition of the library with and without the biological target leads to the identification of a hit compound. Therefore, the synthesis and screening of library members are combined in one step, which speeds-up the process of hit identification.

Moreover, hit identification is possible without any specific receptor assays used. Instead, increased amounts of the highest affinity library members are detected with established analytical methods like HPLC, mass spectrometry (MS), NMR spectroscopy or even X-ray crystallography. ${ }^{9,10}$ It may be more advantageous for the library to amplify many members with moderate affinities than just a few with high affinities. This behaviour reflects the complex nature of DCLs consisted of members interconnected through a set of equilibrium reactions. ${ }^{11}$ To address these problems numerous theoretical studies of DCLs have been done. ${ }^{12-16}$ The studies suggested that, unless excessive amounts of molecular target are used, good binders have a high probability of being significantly amplified. However, a major limitation for application of DCC in drug discovery is the limited number of reversible covalent reactions appropriate to be used to synthesize DCLs. Drug discovery applications of DCC require the following reaction conditions: (i) reaction at a biologically relevant tem- perature, (ii) compatibility with aqueous media, (iii) reaction at (close to) physiological $\mathrm{pH}$ and (iv) compatibility with the target functional groups. ${ }^{17,18}$ Compatibility with aqueous media is the most challenging condition as there are more reactions that have been developed in organic solvents than under aqueous conditions, thus preventing the use of a wider range of equilibration reactions. Additionally, the use of organic solvents in DCC is limited by the strong tendency of solvents to denature the target (enzyme, receptor, etc.). Examples of DCC applications for the discovery of high affinity ligands for biological receptors have been reported, including formation of DCLs of imines ${ }^{19,20}$ hydrazones, ${ }^{21,22}$ oxime ethers, ${ }^{23}$ sulfides, ${ }^{24}$ disulfides ${ }^{25-28}$ and alkenes. ${ }^{29}$

\section{1. Reversible Imine Formation}

Huc and Lehn were the first to demonstrate the concept of DCC application in drug discovery by identifying inhibitors of carbonic anhydrase (CA) using a DCL of imines formed from amines and aldehydes. ${ }^{19}$ In addition to the fast and reversible nature of condensation between amines and aldehydes to imines, reversible imine formation is very convenient for drug discovery because it yields a Schiff base, a very common motive in metabolites and biologically active compounds. ${ }^{30,31}$ To detect products by HPLC, they "locked-in" the equilibrium by irreversible reduction of imines to corresponding amines using $\mathrm{Na}$ $\mathrm{BH}_{3} \mathrm{CN}$ to fix the composition of the library prior to detection.

Hochgürtel et al. created an imine library by condensing a diamine with more than fifty different ketones in the presence of neuraminidase from an influenza virus (Fig. 1) ${ }^{20}$ After reduction of imines, LC/MS analysis identified several hits (1-4). The negative control experiment included library synthesis in the presence of the bovine serum albumin (BSA). The second control experiment was carried out in the presence of the neuraminidase and Zanamivir, a potent competitive inhibitor of the neuraminidase. On both occasions, initial hit $\mathbf{4}$ was identified. The most abundant compound $\mathbf{3}$ lacked inhibitory potency, whereas the strongest inhibitor 2 was amplified three-fold less than $\mathbf{3}$. The authors suggested that this result could be explained by the lock-in reaction. Actual molecular species undergoing equilibration are imines and hemiaminals. The receptor amplifies the amount of these intermediates that are then reduced to fix the library composition. Reduced products have different structural and electronic properties and their interaction with the biological target may be worse, or better, than originating intermediates. This represents a major drawback for the application of reversible imine formation to the construction of DCLs in the presence of a biological target.

Recent progress in analytical methods used for identification of binders from DCL had enabled access to larger libraries. For example, Guo et al. introduced a 
<smiles>[R]C(=O)C[C@H]1C=C(C(=O)O)C[C@@H](N)[C@H]1N</smiles><smiles>CC(CCc1ccc(O)cc1)N[C@H]1C=C(C(=O)O)C[C@H](N)[C@H]1N</smiles><smiles>CCC(CC)N[C@H]1C=C(C(=O)O)C[C@H](N)[C@H]1N</smiles><smiles>CCCC(CC)N[C@H]1C=C(C(=O)O)C[C@H](N)[C@H]1N</smiles><smiles>CC(N[C@H]1C=C(C(=O)O)C[C@H](N)[C@H]1NC(C)(C)O)C(C)(C)O</smiles>

Figure 1. Formation of a library of potential neuraminidase inhibitors by condensing a diamine with several ketones. ${ }^{20}$

protocol for analysis of imine-based DCL using a suitable size-exclusion chromatography (SEC) column to retain all non-binders from DCL followed by denaturation of eluted protein-ligand complexes and MS analysis of binders. ${ }^{32}$

\section{2. Disulfide Interchange}

To demonstrate utility of a disulfide interchange for DCC approach, Ramström and Lehn designed a DCL of disulfides capable of binding to concavalin A (Con A), a member of lectins. ${ }^{25,33}$ DCL of disulfide carbohydrate dimers (Table 1) was generated by incubating disulfide dimers with an initiating reagent dithiothreitol (DTT) capable of reducing some disulfides to thiols. DTT is oxidized to a stable 6-membered cyclic disulfide that should not take part in the interconversion of the library disulfides. Upon initiation, interconversion between disulfides occurred with the rate dependent on $\mathrm{pH}$. At $\mathrm{pH} 7.4$, a reasonable rate of interconversion was obtained and receptor binding was not affected. Disulfide interchange could be stopped by lowering the $\mathrm{pH}(<5)$ and final equilibrium distribution of DCL analyzed by HPLC. In the absence of any receptor, all expected ditopic combinations were generated in approximately equal amounts. When a receptor Con A was present during the interconversion, a significant amount of the bis-mannoside (Man/Man) and the mannose-containing heterodimers (Man/Gal, Man/Ara, $\mathrm{Man} / \mathrm{Xyl}$ ) was found to be bound to the receptor. ${ }^{25}$ Moreover, receptor-induced shifts in equilibrium resulted in the amplification of mannose-containing dimers, which is in accordance with concepts of the DCC approach.

One of the major drawbacks of using DCL of disulfides to identify potent inhibitors of protein targets is the labile nature of disulfide bond. However, once identified disulfide compounds can be replaced with their carbon

Table 1. Structures of the disulfide-linked carbohydrate dimers. ${ }^{25}$

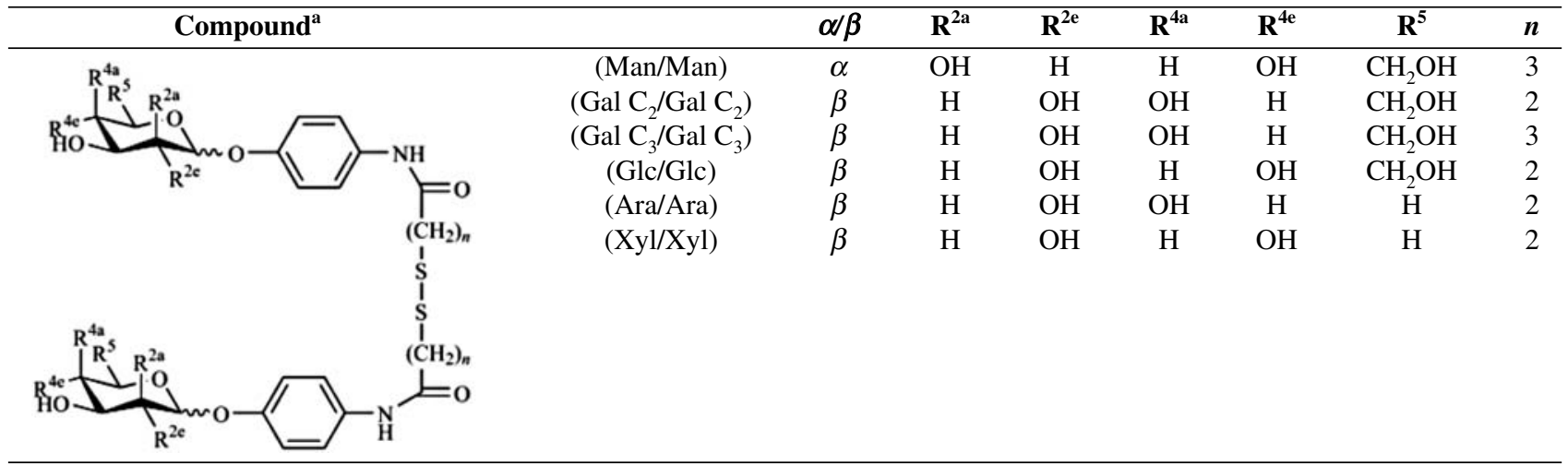

${ }^{\mathrm{a}}$ Man = D-mannose; Gal C $2=\mathrm{D}$-galactose, $n=2 ;$ Gal C 3 = D-galactose, $n=3 ;$ Glc = D-glucose; Ara = L-arabinose; Xyl = D-xylose 
analogues, with bioisosteric thioether or amide linker instead of the disulfide bond. Using modified MS analysis that enables analysis of DCLs of thiols/disulfides under non-denaturing conditions, Schofield et al. have identified inhibitors to various protein targets by preparing carbon analogues of identified disulfide compounds. ${ }^{27,34}$

\section{3. Reversible Acylhydrazone Formation}

Ramström et al. developed DCLs of constituents potentially capable of binding to plant Con A using reversible hydrazidecarbonyl/acylhydrazone inter-conversion. ${ }^{21}$ Acylhydrazone libraries were generated from a series of oligohydrazide core building blocks $\mathbf{A}-\mathbf{I}$ and a set of aldehyde counterparts $\mathbf{5}-\mathbf{1 0}$ based on six common, naturally occurring carbohydrates, potentially capable of interacting with the binding site of Con A (Fig. 2). A set of initial 15 building blocks could give rise to a library containing at least 474 different species. Also, 15 sub-libraries were formed by mixing all building blocks except one specific hydrazide or aldehyde building block under the same conditions. ${ }^{21}$ Following equilibration libraries were subsequently subjected to the lectin assay in which the inhibitory potency of library constituents was monitored.

The resulting inhibitory effects of the sub-libraries have been matched to the activity of the complete library. The largest effect was noticed on the removal of the mannose unit from complete DCL indicating that the mannose unit is necessary for inhibition. Similarly, trivalent core building block $\mathbf{G}$ was the most active. The effect of the compound assembled from these two fragments was estimated in a binding assay, resulting in an $\mathrm{IC}_{50}$ value in the micromolar range $(22 \mu \mathrm{M})$, indicating that the DCC approach using reversible hydrazidecarbonyl/acylhydrazone interconversion enabled the identification of a novel tritopic mannoside showing potent binding to Con A (Fig. 3).

However, the full potential of acylhydrazone-based DCLs in drug discovery is somewhat limited because of the requirement for acidic $\mathrm{pH}$ which is incompatible with most protein targets. Greaney et al. have managed to circumvent this obstacle by introducing nucleophilic catalysis of reversible acylhydrazone formation by using aniline as a nucleophilic catalyst at less acidic $\mathrm{pH}$ and thus identify acylhydrazone inhibitors of GST isozymes. ${ }^{35,36}$<smiles>NNC(=O)CCCCCCC(=O)NNC(=O)[C@@H]1C[C@@H](C(N)=O)C[C@H](C(=O)NN)C1</smiles>

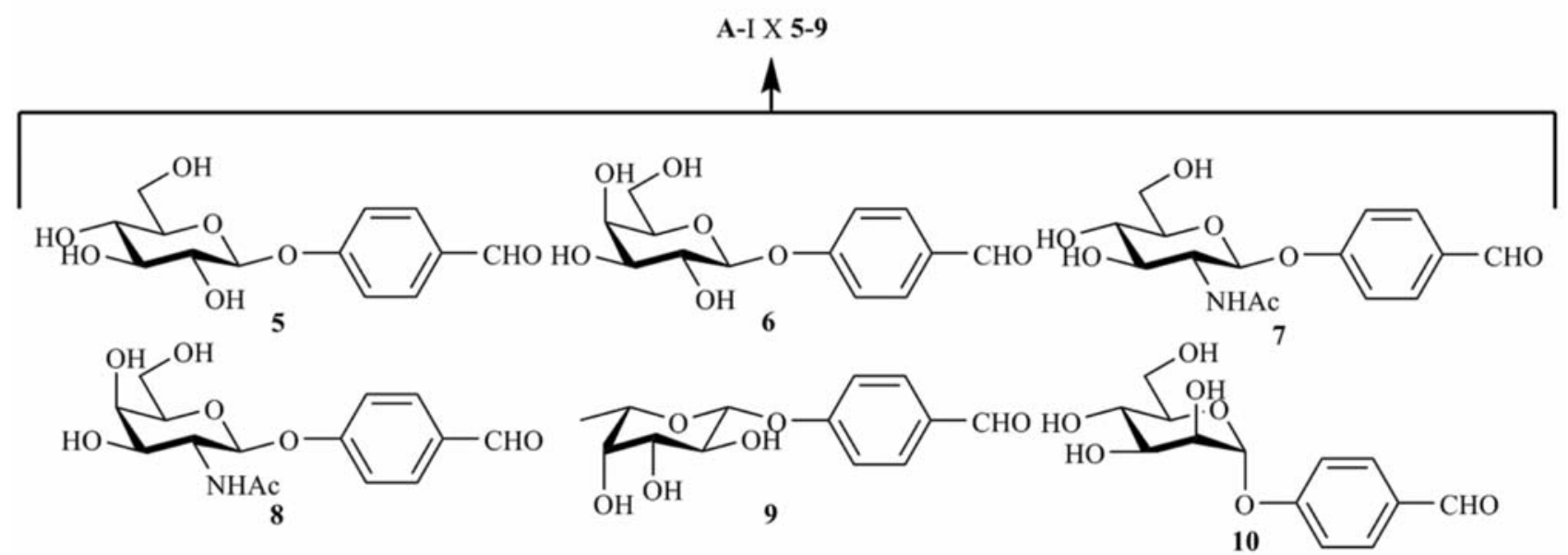

Figure 2. A series of oligohydrazide A-I and aldehyde building blocks 5-10 generating an acylhydrazone dynamic combinatorial library of potential plant lectin Con A inhibitors. ${ }^{21}$ 


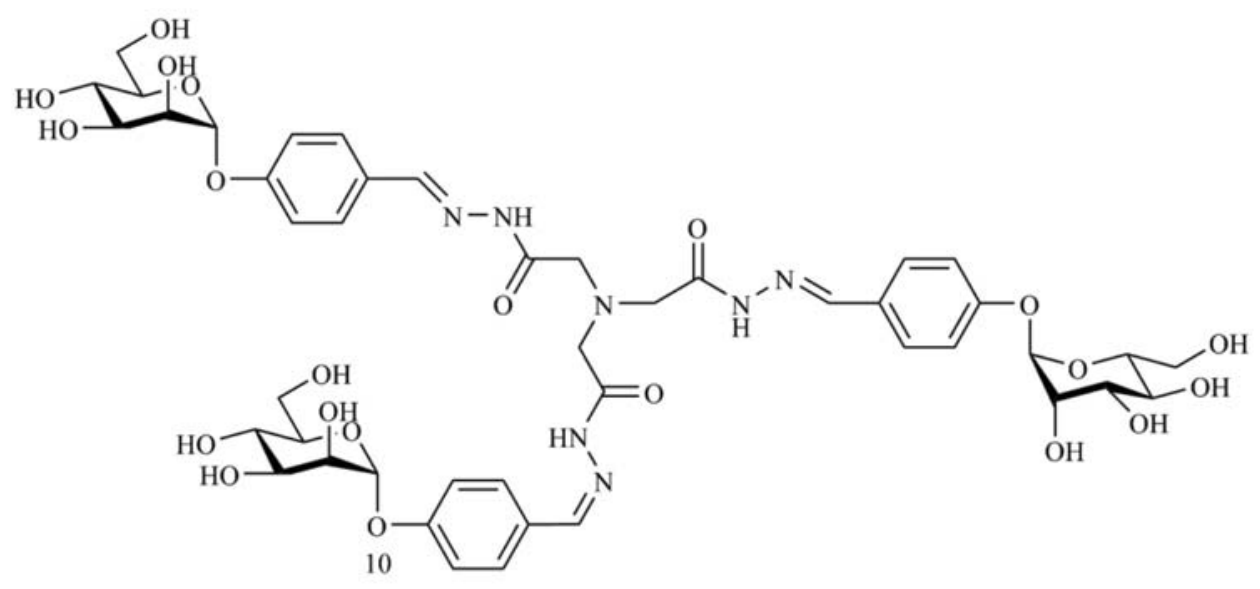

$10_{3}-\mathbf{G}$

Figure 3. Compound $\mathbf{1 0}_{3}-\mathbf{G}$ identified as the best binder to $\mathrm{Con} \mathrm{A}\left(\mathrm{IC}_{50}=22 \mu \mathrm{M}\right)$ from the acylhydrazone dynamic combinatorial library generated from a series of oligohydrazide and aldehyde building blocks. ${ }^{21}$<smiles>N[C@@H](CCC(=O)N[C@@H](CS)C(=O)NCC(=O)O)C(=O)O</smiles><smiles>N[C@@H](Cc1ccccc1)C(=O)N[C@@H](CS)C(=O)NCC(=O)O</smiles>

H-Phe-Cys-Gly-OH, 14<smiles>C=C(CC)C(=O)c1ccc(OCC(=O)O)c(Cl)c1Cl</smiles>

$\mathrm{pH} 7.5$,

(Tris $50 \mathrm{mM}$ )

EA, 12<smiles>CC(C)[C@H](N)C(=O)N[C@@H](CS)C(=O)NCC(=O)O</smiles>

H-Val-Cys-Gly-OH, 13<smiles>NCC(=O)N[C@@H](CS)C(=O)NCC(=O)O</smiles>

H-Gly-Cys-Gly-OH, 15<smiles>N[C@@H](CCC(=O)N[C@@H](C[18O])C(=O)NCC(=O)O)C(=O)O</smiles>

16<smiles>CCCC[C@H](NC(=O)[C@H](N)Cc1ccccc1)C(=O)NCC(=O)O</smiles>

18<smiles>CC(C)[C@H](N)C(=O)N[C@@H](C[18O])C(=O)NCC(=O)O</smiles>

17<smiles>NCC(=O)N[C@@H](C[18F])C(=O)NCC(=O)O</smiles>

19

Figure 4. Dynamic combinatorial library composed of glutathione (GSH) conjugates potentially capable of binding to glutathione S-transferase (GST) generated from GSH, GSH analogues, and ethacrynic acid (EA). ${ }^{37}$ 


\section{4. Conjugate Addition of Thiols to Enones}

Shi and Greaney extended the number of reversible chemical reactions suitable for DCL generation by using conjugated addition of thiols to enones. ${ }^{24} \mathrm{Shi}$ and Greaney designed a biased DCL generated using glutathione (GSH; 11), three GSH analogues 13-15, and the enone ethacrynic acid (EA; 12) (Fig. 4$)^{37}$ Three analogues were expected to be misfits for the $\mathrm{G}$ site of glutathione Stransferase (GST) since the $\gamma$-glutamyl residue is critical for binding, ${ }^{38}$ thus biasing the DCL equilibrium composition in the presence of GST toward the GSH adduct $\mathbf{1 6}$. EA is an inhibitor of GST and has provided a structural scaffold for development of GST inhibitors. Blank DCL, assembled in the absence of GST resulted in the distribution of four conjugates 16-19. Upon incubation with GST from Schistosoma japonica (SjGST), DCL reduced to the expected GS-EA adduct $\mathbf{1 6}$. Adduct $\mathbf{1 6}$ was increased from $35 \%$ of total conjugate concentration to $92 \%$ at equilibrium, due to large differences in binding affinity between $\mathbf{1 6}$ and peptides lacking the $\gamma$-glutamyl residue. Control experiments with BSA instead of SjGST produced no changes to the blank DCL composition, confirming that the active site of SjGST is responsible in amplification of $\mathbf{1 6}$.

Shi et al. used the thiol addition methodology to create new GST inhibitors from nonbiased DCLs. Since

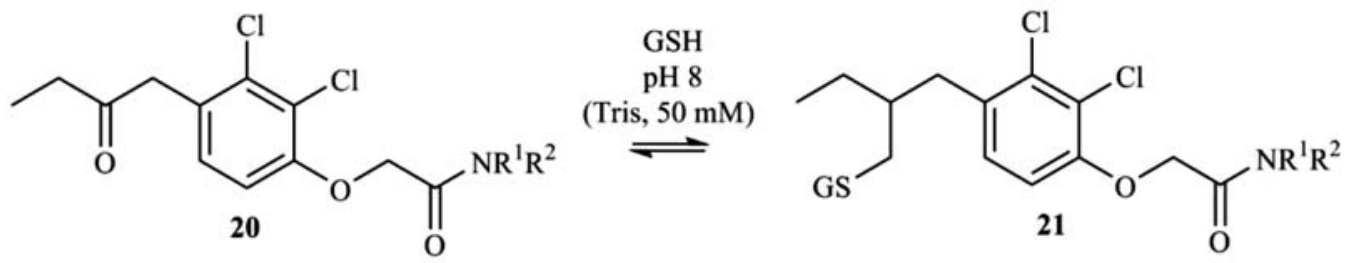

$N R^{1} R^{2}$ :

a)<smiles>CN1CCCCC1</smiles>

b)<smiles>CN1CCOCC1</smiles>

c)<smiles>CNCC(=O)OC</smiles>

d)<smiles>CNCC(F)(F)F</smiles>

e)<smiles>CN1CCCC1</smiles>

f)<smiles>CN[C@@H](CCCCN)C(=O)O</smiles>

j)<smiles>CN1CCC[C@H]1C(=O)O</smiles><smiles>CN[C@@H](CO)C(=O)O</smiles>

h)<smiles>CN[C@@H](CCC(=O)O)C(=O)O</smiles>

k)<smiles>COC(CN(C)C)OC</smiles>

i)<smiles>CN[C@@H](Cc1cc2ccccc2[nH]1)C(C)=O</smiles>

I)<smiles>CCN(C)C1CCCCC1</smiles>

m)<smiles>CN[C@@H](Cc1ccccc1)C(=O)O</smiles>

n)<smiles>CN[C@@H](CC(C)C)C(=O)O</smiles>

Figure 5. A nonbiased DCL of potential GST inhibitors generated from glutathione (GSH) and 14 enone ethacrynic acid analogues. ${ }^{37}$ 
structural features of the $\mathrm{H}$ site change across different GST isozymes, the authors explored the H site of SjGST by constructing a DCL with reversed stoichiometry from that in biased DCL, whereby 14 EA analogues reacted with GSH to afford 14 GS-EA adducts (Fig. 5). MS analysis and deconvolution studies revealed that adducts $\mathbf{2 1 a}, \mathbf{m}$ and $\mathbf{n}$ were amplified in the presence of SjGST, while adduct 21f was suppressed. To examine the inhibition potency of SjGST, 21a, 21n, non-amplified adduct 21b, and the suppressed adduct $21 \mathbf{f}$ were synthesized and their $\mathrm{IC}_{50}$ values measured. Results indicated that the extent of DCL amplification reflected the relative binding affinities of DCL components for the SjGST. Piperidine and leucine amides 21a $\left(\mathrm{IC}_{50}=0.61 \mu \mathrm{M}\right)$ and $21 \mathbf{n}\left(\mathrm{IC}_{50}=1.40 \mu \mathrm{M}\right)$ were amplified from the library at the expense of the weaker binder lysine amide $21 \mathbf{f}\left(\mathrm{IC}_{50}=8.2 \mu \mathrm{M}\right)$. Moreover, contrary to the proposed model structure of the SjGST/GS-EA Michaelis complex which identified a series of residues that could interact with the EA carboxylic acid group, ${ }^{39}$ amplified adducts $21 \mathbf{a}$ and $21 \mathbf{n}$ indicated that the carboxylic acid group of EA is not essential for binding in the $\mathrm{H}$ site and may be extended without change of inhibitory activity.

\section{Receptor-Accelerated Synthesis}

Receptor-accelerated synthesis (RAS), also called kinetically controlled TGS, is a subset of RACC, which uses kinetic control to increase the relative amounts of the highest-affinity library members during library generation. ${ }^{4,40}$ While the library members in the DCC approach are generated via reversible reactions, RAS uses building blocks which irreversibly combine into larger molecules.
Process of hit identification and optimization takes advantage of combining synthesis and screening into one step (Fig. 6). Step 1 includes synthesis of reactive building blocks, while in step 2 these building blocks irreversibly combine due to the presence of a receptor. The hit identification consists of determining whether a formation of a product is significantly accelerated in the presence of a target molecule (receptor).

The selectivity for one or more products over others arises from two factors, one related to the binding of building blocks to the receptor, and the other to the ability of a receptor to accelerate their irreversible joining. With regard to the binding of the starting building blocks to the receptor, simultaneous binding of highest-affinity building blocks in close proximity leads to rate acceleration. However, upon joining the starting building blocks to the product, the binding interactions of building blocks to the receptor may strengthen or weaken in accordance with the Fischer's lock and key model. Thus, highest-affinity building blocks might not form a product with the highest affinity for the receptor. As far as the ability of a given receptor to promote the coupling of reactive building blocks is concerned, it is important to note that receptors do not normally act as coupling catalysts. The demands for a reaction suitable for RAS are different from the DCC approach or from a conventional organic reaction. Ideally, complementary reactive groups should combine very slowly in solution generating a stable product with no or only minor side products. Kolb et al. identified Huisgen's cycloaddition as the one having the ideal reactivity profile for RAS. ${ }^{41,42}$ This methodology has been successfully applied in numerous examples known as in situ click chemistry. ${ }^{43}$ So far, RAC approaches have included $\mathrm{C}-\mathrm{N}$ bond formation, ${ }^{44-46}$ $\mathrm{C}-\mathrm{S}$ bond formation, ${ }^{47-49} \mathrm{C}-\mathrm{C}$ bond formation, ${ }^{50}$ and ami-

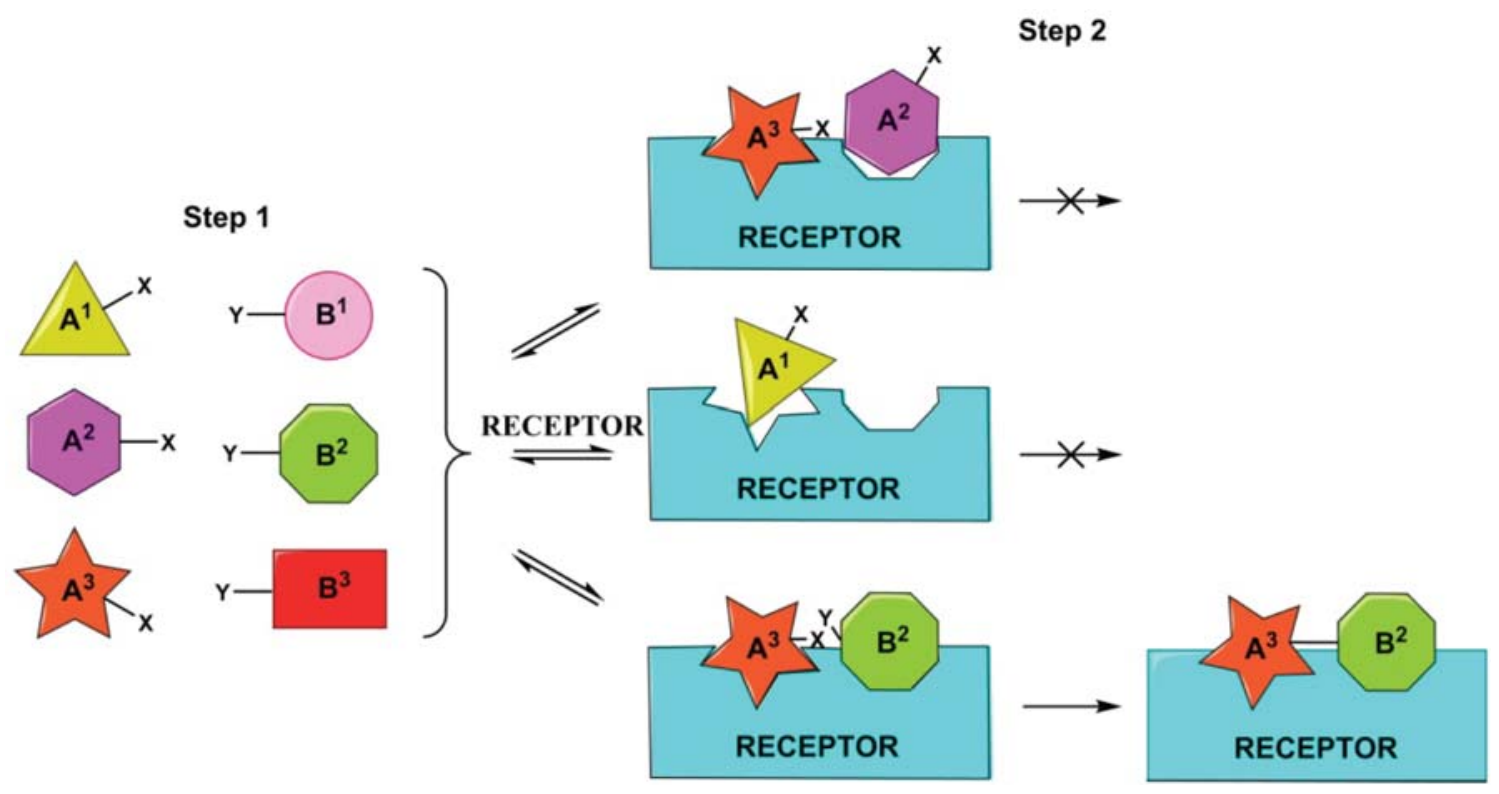

Figure 6. Receptor-accelerated synthesis for hit discovery and optimization. Products are created from blocks properly stabilized within the receptor. 
de formation from thio acids and sulfonyl azides, also referred to as "sulfo-click reaction". ${ }^{51,52}$ Some of these approaches are described in more detail below.

\section{1. Substitution Reaction Using a Thiol as the Nucleophile}

Huc and Nguyen were the first to demonstrate the utility of a substitution reaction using a thiol as a nucleophile for the identification of an inhibitor via RAS approach.$^{47}$ This reaction is widely used in organic chemistry since thiols are more reactive than alcohols. In initial study, they chose to target a zinc-containing metalloenzyme, bovine CA-II (EC 4.2.1.1).$^{53}$ CA-II isozymes play a role in many important biological processes, including respiration, bone respiration, calcification, acid secretion, and $\mathrm{pH}$ control. The CA-II active site is a conical cleft with the $\mathrm{Zn}(\mathrm{II})$ ion located at its bottom with two secondary hydrophobic binding sites located in close proximity of this cleft. They tested the ability of CA-II to accelerate the formation of para-substituted aromatic sulfonamide inhibitors 24a-e using competition assays optimized to limit side reactions, such as disulfide formation, alkyl chloride hydrolysis, and trialkyl sulfonium formation (Fig. 7). ${ }^{47}$

Thiol 22 was treated with two competing alkyl chlorides in buffered water at $\mathrm{pH} 6$ for $48 \mathrm{~h}$, first in the absence of CA-II, then in the presence of CA-II. HPLC analysis of the final thioether products confirmed that CA-II strongly favours formation of more potent inhibitors. For example, when chloride 23a competes with $\mathbf{2 3 d}$, the yield of more potent inhibitor $\mathbf{2 4 d}$ changes from $50 \%$ in the absence of CA-II to $92 \%$ in its presence. On the contrary, when products have similar affinities for CA-II, their final yields are negligibly affected by the presence of CA-II. To confirm that CA-II serves as the reaction vessel, Huc and Nguyen conducted several control experiments, including varying CA-II concentration, replacing CA-II by BSA, replacing thiol 22 by a thiol that has no affinity for CA-II, and adding an inhibitor of CA-II, methazolamide. ${ }^{54}$ All of these experiments confirmed that the active site of CA-II templates product formation.

Besides alkyl halides, thiols can also react with epoxide rings in protein-templated irreversible formation of biologically active ligands. Okhanda et al. have utilized such epoxide ring opening to identify inhibitors of recombinant human 14-3-3 protein, involved in immunoglobulin class switching, via RAS approach. ${ }^{48}$

\section{2. Amide Formation Between Thio Acids and Sulfonyl Azides}

The choice of biological target for the RAS or the RACC is not limited to enzymes only. It has been shown that RAS can be utilized to discover small molecules that modulate or disrupt protein-protein interactions (PPIs) called protein-protein interaction modulators (PPIMs). PPIs are crucial for a large number of vital biological processes and interesting in the development of novel therapies for a variety of diseases. ${ }^{55}$ Among PPI targets for cancer treatment are also proteins of the Bcl-2 family. Some of the $\mathrm{Bcl}-2$ proteins act as anti-apoptotic proteins ( $\mathrm{Bcl}-2$,<smiles>[R19]Cc1ccc(S(=O)(=O)N[C@H](C)[C@H](C)[C@H](C)Cl)cc1</smiles><smiles>NC(=O)CSCc1ccc(S(N)(=O)=O)cc1</smiles><smiles>CC(=O)CSCc1ccc(S(N)(=O)=O)cc1</smiles><smiles>CCOC(=O)CC(=O)CSCc1ccc(S(N)(=O)=O)cc1</smiles><smiles>NS(=O)(=O)c1ccc(CSCc2ccc(C(=O)O)cc2)cc1</smiles>

24a

$K_{\mathrm{i}}=770 \mathrm{nM}$

$24 \mathrm{c}$

$K_{\mathrm{i}}=130 \mathrm{nM}$

$K_{\mathrm{i}}=84 \mathrm{nM}$<smiles>NS(=O)(=O)c1ccc(CSCc2cccc(C(=O)O)c2)cc1</smiles>

$K_{\mathrm{i}}=59 \mathrm{nM}$

Figure 7. The formation of para-substituted aromatic sulfonamide inhibitors $\mathbf{2 4 a - e}$ of CA-II. ${ }^{47}$ 
<smiles>O=C(NS(=O)(=O)c1ccc(NCCSc2ccccc2)c([N+](=O)[O-])c1)c1ccc(-c2ccc(F)cc2)cc1</smiles><smiles>CN(C)CC[C@H](CSc1ccccc1)Nc1ccc(S(=O)(=O)NC(=O)c2ccc(N3CCN(Cc4ccccc4-c4ccc(Cl)cc4)CC3)cc2)cc1[N+](=O)[O-]</smiles><smiles>[Y19]C([14CH3])([14CH3])S(=O)(=O)c1cc(S(=O)(=O)NC(=O)c2ccc(N3CCN(CC4=C(c5ccc(Cl)cc5)CC(C)(C)CC4)CC3)cc2)ccc1N[C@H](CCN1CCOCC1)CSc1ccccc1</smiles>

Figure 8. $N$-Acylsulfonamide compounds targeting $\mathrm{Bcl}-\mathrm{X}_{\mathrm{L}} \cdot{ }^{57-59}$

Bcl- $\mathrm{X}_{\mathrm{L}}$, and Mcl-1) and others as pro-apoptotic proteins. Pro-apoptotic proteins can be further classified into multidomain BH1-3 proteins (Bax and Bak) and BH3-only pro- teins (Bad, Bim, and Noxa) ${ }^{56} \mathrm{Bcl}-2$ proteins play an important role in the apoptosis. Most likely, apoptosis is initiated by binding the $\mathrm{BH} 3$ domain of $\mathrm{BH} 3$-only proteins<smiles>CC1(C)CCN(c2ccc(C(=O)S)cc2)CC1</smiles>

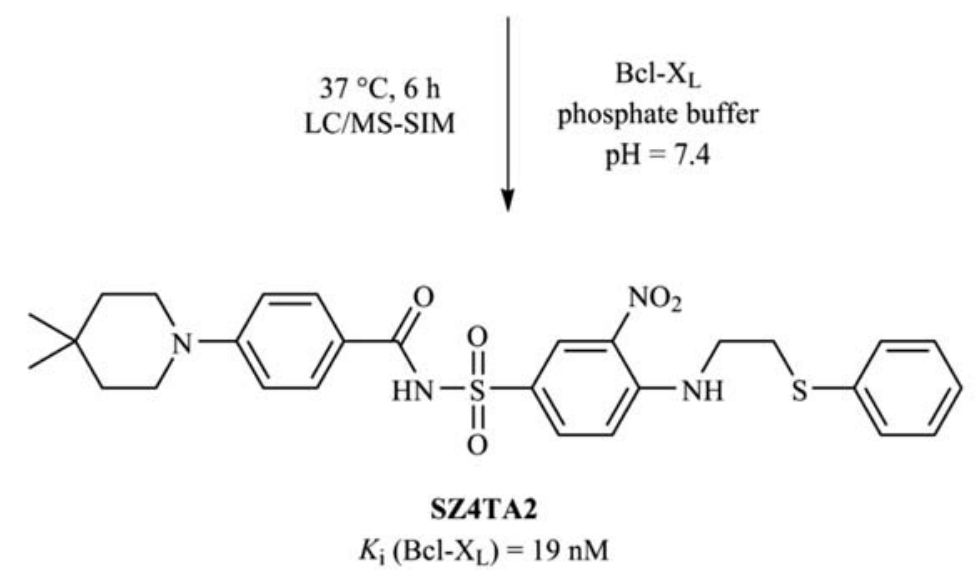

Figure 9. PPIM identification via sulfo-click RAS approach. ${ }^{60}$ 
<smiles>NS(=O)(=O)c1ccc(CN2CCN(c3ccccc3)CC2)cc1</smiles><smiles>CN(CCc1ccccc1)Cc1ccc(S(N)(=O)=O)cc1</smiles><smiles>CC(=O)Nc1ccc(S(N)(=O)=O)cc1</smiles><smiles>NS(=O)(=O)c1ccc(NCCSc2ccccc2)c([N+](=O)[O-])c1</smiles><smiles>Cc1ccc(S(N)(=O)=O)cc1</smiles><smiles>NS(=O)(=O)c1ccc(CNCCS)cc1</smiles>

SZA

SZ5

Sz6<smiles>NS(=O)(=O)c1ccc2ccc(S(=O)(=O)NCCSc3ccccc3)cc2c1</smiles><smiles>COc1cc2c(cc1OC)C(c1ccccc1)N(Cc1ccc(S(N)(=O)=O)cc1)CC2</smiles>

sZ<smiles>NS(=O)(=O)c1ccc(CN(CCSc2ccc(S(N)(=O)=O)cc2)Cc2ccc(S)cc2)cc1</smiles>

SZ9

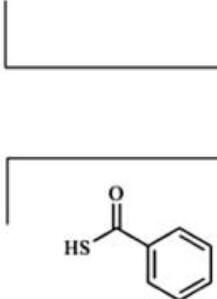

TA1<smiles>COc1cc2c(cc1OC)C(c1ccccc1)N(CC(=O)S)CC2</smiles>

TA4<smiles>NC(=O)c1cccc2ccccc12</smiles>

TA7
TA2<smiles>COc1cc(OC)cc(C(=O)S)c1</smiles><smiles>CCOc1ccc(C(=O)S)cc1</smiles><smiles>Cc1nc(-c2ccccc2)sc1C(=O)S</smiles>

TA3

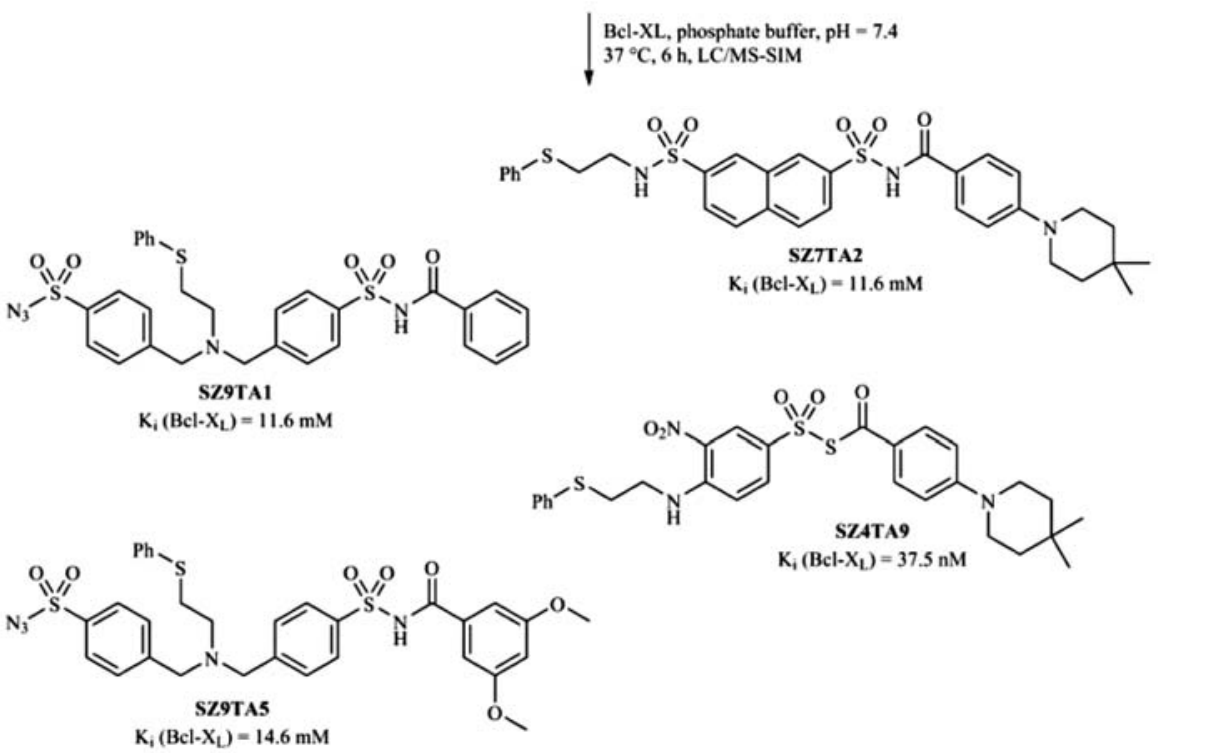

Figure 10. Screening of anti-apoptotic Bcl- $\mathrm{X}_{\mathrm{L}}$ via sulfo-click RAS approach for PPIM discovery. ${ }^{51}$

Maraković and Šinko: The Lock is the Key: Development of Novel Drugs ... 
into a hydrophobic groove on the surface of anti-apoptotic proteins. Therefore, designing a molecule capable of mimicking the $\mathrm{BH} 3$ domain is a promising strategy for novel anticancer treatments. Thus, $N$-acylsulfonamides $\mathbf{2 5}$, ABT-737, and ABT-263, capable of disrupting Bcl- $\mathrm{X}_{\mathrm{L}}-$ Bad interaction, were prepared (Fig. 8). ${ }^{57-59}$

$\mathrm{Hu}$ et al. applied the RAS approach for the discovery of $\mathrm{N}$-acylsulfonamide PPIMs. ${ }^{60}$ They designed building blocks structurally similar to ABT-737 and ABT263, having a sulfonyl azide or a thio acid functional groups, and incubated these as binary mixture together with Bcl-XL for $6 \mathrm{~h}$. LC/MS analysis revealed that, of all the 18 possible products, only $N$-acylsulfonamide SZ4TA2 was detected (Fig. 9).

Control experiments involving incubation of reactive building blocks in the absence of $\mathrm{Bcl}-\mathrm{X}_{\mathrm{L}}$ or in the presence of $\mathrm{Bcl}-\mathrm{X}_{\mathrm{L}}$ and various $\mathrm{BH} 3$-containing peptides, confirmed that the surface of $\mathrm{Bcl}-\mathrm{X}_{\mathrm{L}}$ protein acts as a template for the sulfo-click reaction. To generate new hit compounds, Kulkarni et al. designed two sublibraries, one with thio acids and the other with sulfonyl azides, among which were those with a structural resemblance to ABT-737 or ABT-263 and those that were randomly chosen. ${ }^{51}$ Eighty-one binary mixtures containing one thio acid (TA1-TA9) and one sulfonyl azide (SZ1-SZ9) were incubated with the protein Bcl- $\mathrm{X}_{\mathrm{L}}$ for $6 \mathrm{~h}$ at $37^{\circ} \mathrm{C}$ (Fig. 10).

LC/MS analysis of binary mixtures with or without $\mathrm{Bcl}-\mathrm{X}_{\mathrm{L}}$ present during reaction resulted in elevated amounts of SZ4TA2, and three new products SZ7TA2, SZ9TA1, and SZ9TA6 in the presence of $\mathrm{Bcl}-\mathrm{X}_{\mathrm{L}}$. Control experiments with native and mutated pro-apoptotic Bim $\mathrm{BH} 3$ peptides and $\mathrm{Bcl}-\mathrm{X}_{\mathrm{L}}$ proteins indicated that protein-templated $N$-acylsulfonamide formation happened solely at the binding sites of $\mathrm{Bcl}-\mathrm{X}_{\mathrm{L}}$. In order to evaluate the $\mathrm{IC}_{50}$, all four hit compounds were subjected to dose-response studies and binding studies. ${ }^{60}$ All of the hit compounds show high to modest affinity for $\mathrm{Bcl}-\mathrm{X}_{\mathrm{L}}$ protein and can modulate the interaction between $\mathrm{Bcl}-\mathrm{X}_{\mathrm{L}}$ and $\mathrm{BH} 3$ peptide ligand.

Nature of sulfo-click reaction and substrate scope challenge its applicability in the RAS approach. As thioacids are nucleophilic, readily dimerize, and present storage and stability issues, their preparation and handling is therefore very demanding. ${ }^{61}$ Namelikonda et al. optimized the one-pot deprotection/amidation variant of sulfo-click reaction in the presence and absence of Bcl- $\mathrm{X}_{\mathrm{L}}$ starting from the 9-fluorenylmethyl (Fm)-protected thioesters and sul- fonylazides. ${ }^{52}$ Optimal deprotection of Fm thioesters TA1'-TA3' prepared from thioacid building blocks TA1-TA3 was achieved in one minute at room temperature with 3.5\% 1,8-diazabicycloundec-7-ene (DBU)/DMF. Resulting thioacids TA1-TA3 were immediately diluted with methanol and incubated with sulfonylazides SZ1-SZ6 as binary mixtures in the presence and absence of Bcl- $\mathrm{X}_{\mathrm{L}}$. Product analysis failed to detect an increased amount of the previously reported hit compound SZ4TA2 in the presence of $\mathrm{Bcl}-\mathrm{X}_{\mathrm{L}}$, presumably due to the change in $\mathrm{pH}$ of the incubation sample probably due to the strong basicity of DBU. Experiments were repeated with a weaker base (5\% piperidine/DMF), and the amount of SZ4TA2 was increased to the same level as before containing purified thioacid TA2. However, a side reaction producing piperidine amide was observed, but this unwanted byproduct did not interfere with $\mathrm{Bcl}-\mathrm{X}_{\mathrm{L}}$ templated reaction.

\section{In situ Click Chemistry}

So far, only a RAS approach using a combination of strong nucleophilic (basic) and electrophilic (acidic) building blocks has been discussed. However, a subset of receptor-accelerated synthesis, termed in situ click chemistry, has been developed utilizing the Huisgen's cycloaddition, ${ }^{5,6}$ a reaction independent to the acid-base reactivity paradigm, as shown in literature. ${ }^{62-67}$

\section{1. The Huisgen's 1,3-Dipolar Cycloaddition}

The Huisgen's 1,3-dipolar cycloaddition of azides and alkynes to form 1,2,3-triazoles is a model example among the reactions that meet the criteria of click chemistry (Fig. 11). ${ }^{41}$ Originally introduced by Barry Sharpless in 1999, click chemistry refers to a group of reactions that generate carbon-heteroatom bonds.

Click chemistry has been successfully applied in many areas, including organic synthesis, ${ }^{68-72}$ bioconjugation, ${ }^{73-75}$ drug discovery, ${ }^{4,24,76,77}$ and polymer and material sciences. ${ }^{78-81}$ Huisgen's cycloaddition is preferred since azides and alkynes are easy to implement and are inert in the acidic/basic environments and under physiological conditions. However, spontaneous cycloaddition is very slow, since reaction proceeds only if azide and alkyne in-

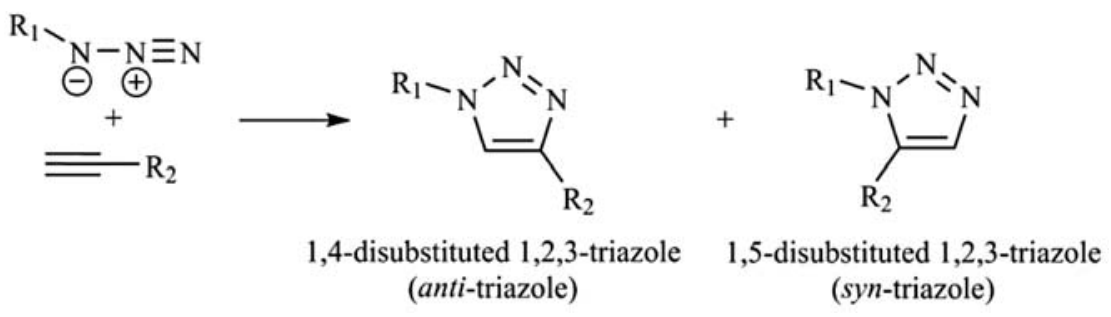

Figure 11. Huisgen's 1,3-dipolar cycloaddition of azides and alkynes. ${ }^{41}$ 
teract properly oriented. It was only after the discovery of dramatic rate acceleration of the azide-alkyne cycloaddition under copper(I) catalysis that it gained its popularity. ${ }^{82,83}$ This reaction exclusively forms 1,4 -disubstituted 1,2,3-triazoles (anti-triazoles). The 1,5-disubstituted 1,2,3-triazoles (syn-triazoles) are prepared by using magnesium acetylides or ruthenium catalysis. ${ }^{84,85}$ Recently, efficient recyclable nanocatalysts have been developed for regioselective synthesis of 1,2,3-triazoles in water. ${ }^{86}$ Thermal reaction is extremely slow and gives a mixture of isomers which are chromatographically separable. In addition, 1,2,3-triazole moieties have some favourable physicochemical properties attractive for application to the drug discovery and biomedicine. They are very stable to both metabolic and chemical degradation, being inert to hydrolytic, oxidizing, and reducing conditions, even at higher temperatures. ${ }^{25}$ Due to resemblance with amide moiety in size, dipolar moment, and H-bond acceptor capacity, the 1,2,3-triazole ring can serve as its non-classic bioisostere. ${ }^{44,45,87,88}$ Since 1,2,3-triazoles are basic aromatic heterocyclic compounds, they are bioisosteres of aromatic rings and double bonds. ${ }^{65,66}$ Additionally, the aforementioned physicochemical properties of 1,2,3-triazole moiety together with similarity to amide bond, make it a useful linker to generate "twin drugs", ${ }^{42,67,83}$ bidentate inhibitors, ${ }^{83-85,89}$ linkers to immobilized fluorescent tags or small molecules, ${ }^{71}$ and anion receptors. ${ }^{90}$

\section{2. In situ Click Chemistry Using Acetylcholinesterase as a Template}

Inspired by a report by Mock et al. on dramatic rate acceleration of azide and alkyne cycloaddition by sequestering azide and alkyne moieties inside the cavity of cu-<smiles>Nc1ccc2c3ccc(N)c(-[n+]4c5cc(N)ccc5c5ccc(N)cc5[n+]4CCCCCCc4cnnn4CCNc4c5c(nc6ccccc46)CCCC5)cc-3c(-c3ccccc3)c2c1</smiles>

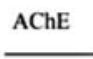<smiles>Nc1ccc2c(c1)C(c1ccccc1)=NN(CCCCCn1nncc1CCNc1c3c(nc4ccccc14)CCCC3)c1cc(N)ccc1-2</smiles><smiles></smiles>

Figure 12. In situ click chemistry screening of binary mixtures of tacrine/phenylphenanthridinium-based building blocks for the discovery of bivalent inhibitors to AChE..$^{91,98}$ 
curbituril, a macrocycle made of glycouril, ${ }^{89}$ Lewis et al. were the first to investigate the potential of Huisgen's cycloaddition for application to target-guided synthesis. ${ }^{91}$ In their proof-of-concept study, they selected enzyme acetylcholinesterase (AChE; EC 3.1.1.7) which plays a vital role in neuro-transmission in central and peripheral nervous system. ${ }^{92,93}$ The active site of $\mathrm{AChE}$ is a narrow gorge with the catalytic binding site located at its bottom. The second binding site, known as peripheral site, is at the rim of the active site. ${ }^{94,95}$ Since reversible AChE inhi-<smiles>C#CCN1CCc2cc(OC)c(OC)cc2C1CC#N</smiles>

IQN-A5: $\mathrm{n}=5$ IQN-A6: $n=6$<smiles>C#CCn1c2ccccc2c2ccccc21</smiles>

C-A5: $\mathrm{n}=5$

C-A6: $n=6$<smiles>C#CCN(c1ccccc1)c1ccccn1</smiles>

DPA-A5: $\mathrm{n}=5$

DPA-A6: $\mathrm{n}=6$<smiles>C#CCN1CCCCC1</smiles>

PIP-A5: $\mathrm{n}=5$

PIP-A6: $\mathrm{n}=6$<smiles>C#CCCCCC=NNc1ccnc2cc(Cl)ccc12</smiles><smiles>C#CCN1CCc2cc(OC)c(OC)cc2C1c1ccccc1</smiles>

PIQ-A5: $\mathrm{n}=5$

PIQ-A6: $\mathrm{n}=6$<smiles>C#CCn1c(=O)c2ccccc2c2ccccc21</smiles>

PO-A5: $n=5$

PO-A6: $n=6$<smiles>C#CCN1CCc2ccccc2C1</smiles>

HIQ-A5: $\mathrm{n}=5$

HIQ-A6: $\mathrm{n}=6$<smiles>C#CCN1CCc2cc(OC)c(OC)cc2C1C(C)C</smiles>

IIQ-A5: $\mathrm{n}=5$

IIQ-A6: $\mathrm{n}=6$<smiles>C#CCOc1nc2ccccc2c2ccccc12</smiles>

PHN-A5: $\mathrm{n}=5$

PHN-A6: $n=6$

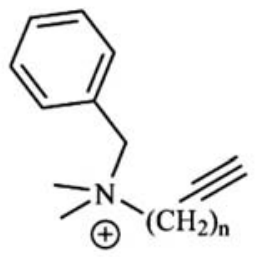

DMB-A5: $\mathrm{n}=5$

DMB-A6: $\mathrm{n}=6$<smiles>C#CCCCCC=NN(C)c1nc(-c2ccccc2)nc2ccccc12</smiles>

PQH-A4<smiles>C#CCCCCC=NN(C)c1ccc([N+](=O)[O-])c2nonc12</smiles>

QH-A4

Figure 13. A library of acetylene building blocks for in situ click chemistry screening of AChE. ${ }^{106}$ 
bitors are used clinically to treat neurodegenerative disorders, such as Alzheimer's disease,${ }^{96}$ various small-molecule ligands specific for each binding site have been developed, together with such which simultaneously bind to both sites and therefore possess higher affinity for AChE. ${ }^{97-99}$ Moreover, dimerization of an inactive fragment of a selective and potent reversible AChE inhibitor Huperzine A has shown that an inactive ligand can be transformed into highly potent inhibitors. ${ }^{100}$ To address the possibility of self-assembly of bivalent AChE inhibitors via Huisgen's cycloaddition, Lewis et al. used a library of known site-specific inhibitors based on tacrine (a catalytic site binder with $K_{\mathrm{d}}$ of $18 \mathrm{nM}$ ) and phenylphenanthridinium (a peripheral site binder with $K_{\mathrm{d}}$ of 1.1 $\mu \mathrm{M})$ derivatized with alkyl chains bearing terminal azide and alkyne moieties (Fig. 12). ${ }^{99,100}$

Each of the binary mixtures was incubated with $\mathrm{AChE}$ at room temperature for 6 days. Upon examination of binary mixtures, it was established that only $\mathbf{T Z 2}+$ PA6 combination gave a detectable amount of the triazole product. ${ }^{101}$ Blocking the active site with reversible (tacrine) or irreversible (diisopropyl fluorophosphate) inhibitor blocked formation of the triazole product, confirming that the active site is a template for reaction. HPLC analysis revealed that the enzyme-templated product is exclusively a syn-izomer. A comparison of the dissociation constant of syn-TZ2PA6 $\left(K_{\mathrm{d}}\right.$ is $\left.77 \mathrm{fM}\right)$ and anti-TZ2PA6 $\left(K_{\mathrm{d}}\right.$ is $720 \mathrm{fM}$ ) showed that AChE templated the formation of a more potent inhibitor. Comparison of kinetic parameters and literature data for related non-covalent inhibitors of AChE, revealed that in situ generated syn-TZ2PA6 was the most potent non-covalent $\mathrm{AChE}$ inhibitor known at the time. ${ }^{99,102-104}$

Manetsch et al. revisited the AChE system to screen for additional in situ hits. ${ }^{105}$ LC/MS analysis revealed three new hit compounds - TZ2PA5, TA2PZ6, and TA2PZ5 - in addition to the TZ2PA6. All of the products were identified as syn-isomers with dissociation constants in femtomolar and picomolar range. Krasiñski et al. substituted phenylphenanthridinium moeity with aromatic heterocycles that were not previously known to interact with AChE while tacrine building block TZ2 was chosen as an "anchor molecule" (Fig. 13). ${ }^{106}$

Analysis of binary TZ2/acetylene mixtures with AChE revealed that only phenyltetrahydro-isoquinolines PIQ-A5 and PIQ-A6 formed significant amounts of triazole products identified as syn-isomers. Incubation of a mixture of 10 acetylene building blocks with TZ2 and AChE gave only expected triazole products TZ2PIQ-A5 and TZ2PIQ-A6 demonstrating the feasibility of multicomponent screening. With the equilibrium dissociation constant of only $33 \mathrm{fM}$, TZ2PIQ-A5 surpasses the inhibition potency of syn-TZ2PA6.

Beside the development of potent reversible AChE inhibitors for treating Alzheimer's disease, another kind of medical treatment has preoccupied the attention of researc- hers in the field. Organophosphorus (OP) nerve agents acting as irreversible AChE inhibitors represent a constant threat to the general population because of their use as warfare agents in armed conflicts and terrorist attacks or as pest control agents. ${ }^{107,108}$ Thus, the current therapy in case of OP nerve agent poisonings includes an AChE reactivator of the quaternary pyridinium oxime family. ${ }^{109,110} \mathrm{Ho}-$ wever, due to their permanent positive charge, these compounds do not readily cross the blood-brain barrier and thus cannot reactivate $\mathrm{AChE}$ in the central nervous system. ${ }^{111}$ Therefore, attempts have been made to develop centrally acting reactivators using click-chemistry approach. ${ }^{112,113}$ The AChE related enzyme butyrylcholinesterase $(\mathrm{BChE})$ is present in the plasma in high concentrations and differs in the amino acid composition. ${ }^{114,115} \mathrm{BCh}$ $\mathrm{E}$ is capable of hydrolyzing a variety of esters and plays an important role in the bioconversion of carbamates and other ester-based prodrugs. ${ }^{116-118}$ Both AChE and BChE display selectivity and stereoselectivity in interaction with reversible or irreversible inhibitors, various esters and carbamates. ${ }^{119-123}$ The in situ click-chemistry approach may help in the development of novel chiral reactivators tailored by cholinesterase itself thus avoiding cumbersome synthetic procedures and/or enantiomer separation.

\section{3. In situ Click Chemistry Experiments with Acetylcholine Binding Protein}

Recently, Grimster et al. reported the preparation of ligands for nicotinic acetylcholine receptors (nAChRs) via in situ click chemistry thus expanding the templation potential of this approach to more flexible intersubunit binding sites. ${ }^{124}$ As a member of a superfamily of neurotransmitter ligand-gated ion channels, nAChRs have been investigated as therapeutic targets for medical treatment of central nervous system (CNS) disorders such as schizophrenia, nicotine addiction, and Alzheimer's disease. ${ }^{125-127}$ However, the development of novel and potent ligands for specific receptor subtypes using classical drug discovery approaches has been difficult because of the nAChR membrane disposition, receptor subtypes diversity, and the dynamic nature of the binding site. Grimster et al. turned their attention to the in situ click chemistry approach with the acetylcholine binding protein $(\mathrm{AChBP})$ as a structural surrogate for $\mathrm{n}$ AChRs. ${ }^{124}$ AChBPs are homologous to the $N$-terminal 210 amino acids in the extracellular receptor domain with flexible subunit interface, thus imitating recognition properties of nAChRs. Initially, screening the triazole library synthesized under standard $\mathrm{Cu}$-catalyzed azide alkyne cycloaddition reaction conditions against AChBPs from Lymnaea stagnalis (Ls), Aplysia californica $(A c)$, and the Y55W Aplysia californica mutant $(A c \mathrm{Y} 55 \mathrm{~W})$ revealed compound $\mathbf{2 6}$ as the strongest binder to all three nAChR surrogates, with the dissociation constant in the nanomolar range for $L s$ AChBP (Fig. 14). 


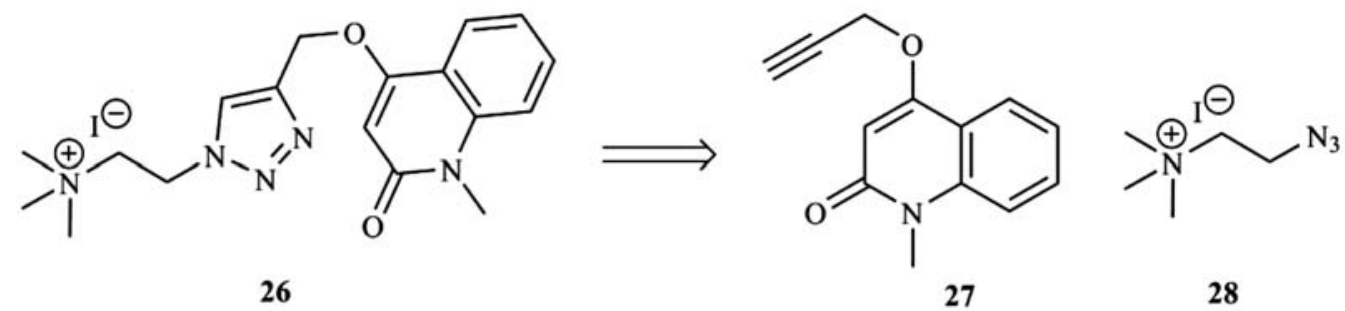

Figure 14. Compound 26 with high affinity to Lymnaea stagnalis, Aplysia californica, and the Y55W Aplysia californica mutant AChBPs and constituent alkyne $\mathbf{2 7}$ and azide $\mathbf{2 8}$ shown in retrosynthetic representation. ${ }^{124}$

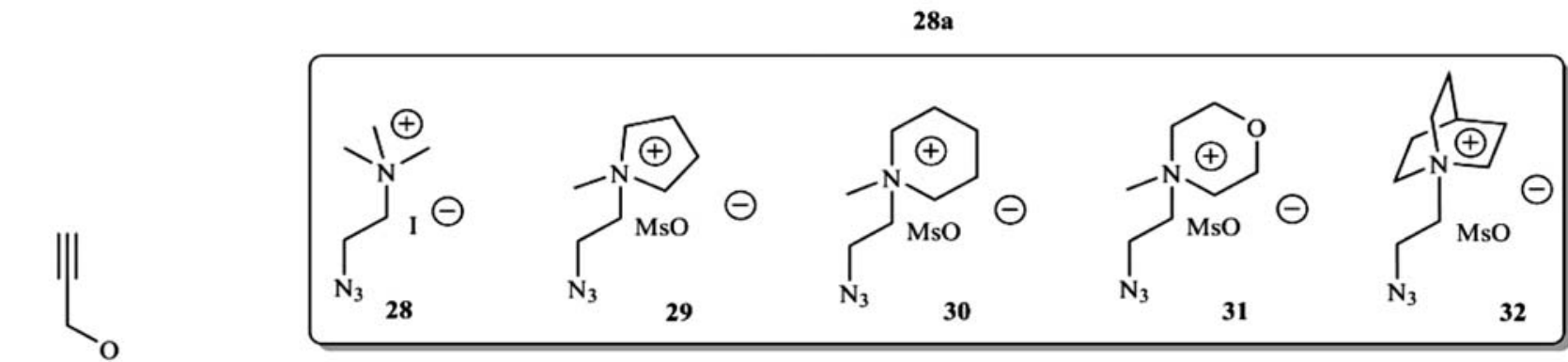<smiles>[X]c1ccc2c(c1)c(OC)cc(=O)n2C</smiles><smiles>CN1C2CCC1C(CCCN)CC(N)C2</smiles>

$28 b$

AChBP<smiles>Cn1c(=O)cc(OCc2cn(CC[N+](C)(C)C)nn2)c2ccccc21</smiles>

26

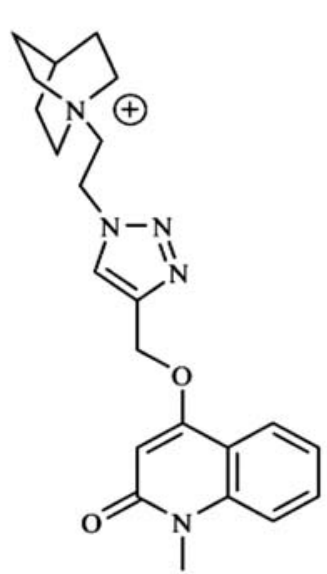

38
39

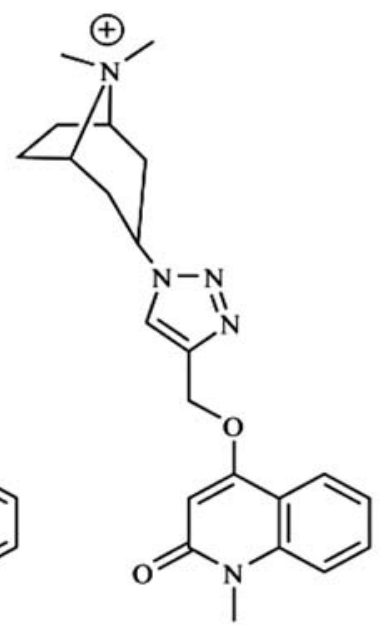

40

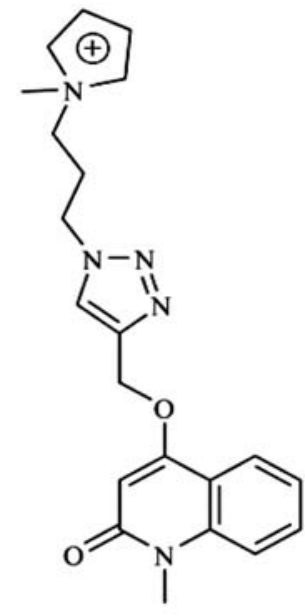

41

Figure 15. In situ click chemistry screening of azide libraries $\mathbf{2 8 a}$ and $\mathbf{2 8 b}$ against alkyne $27 .{ }^{124}$ 
To confirm that flexible subunit interfaces in the AChBPs are capable to template the formation of $\mathbf{2 6}$, the constituent alkyne $\mathbf{2 7}$ and azide $\mathbf{2 8}$ were incubated in the presence of $L s, A s$, and $A c Y 55 \mathrm{~W}$ AChBPs in sodium phosphate buffer at room temperature for 3 days. Analysis of the reaction mixture by LC/MS-SIM method confirmed that $L s$ AChBP successfully catalyzed the formation of compound 26, while both $A c$ and $A c \mathrm{Y} 55 \mathrm{~W}$ AChBPs gave the product but in much lower amount. Control reaction with $L s$ AChBP inhibited with a known competing ligand methyllycaconitine (MLA) gave a relatively low amount of product, thus confirming that the ACh binding site at flexible subunit interface indeed served as the template for the cycloaddition reaction. The search for new compounds with improved affinity and selectivity for closely related AChBPs continued using triazole 26 as a lead. Azide libraries 28a and $\mathbf{2 8 b}$ comprising building blocks with quaternary nitrogen centers, were incubated with alkyne $\mathbf{2 7}$ in the presence of $L s, A s$, and $A c \mathrm{Y} 55 \mathrm{~W}$ AChBPs at room temperature for 3 days (Fig. 15).

LC/MS-SIM analysis revealed that $L s$ AChBP catalyzed the formation of triazole products $26,38,39,40$, and 41 more efficiently than $A c$ or $A c$ Y55W AChBPs. It was also shown that the amount of in situ generated product is related to its affinity to the specific AChBP. For instance, the most amplified triazole $\mathbf{4 0}$ was shown to possess the highest affinity $\left(K_{\mathrm{d}}=0.96 \mathrm{nM}\right)$ to $L s$ AChBP. Next, the alkyne library with the previously tested quinolone derivative $\mathbf{2 7}$ and diversely substituted aryl propargyl ethers was incubated with azide $\mathbf{3 3}$ in the presence of $L s, A c$, and AcY55W AChBPs. LC/MS-SIM analysis revealed that all of the tested alkynes underwent AChBPtemplated cycloaddition reactions with azide 33. However, the previously described triazole $\mathbf{4 0}$ was again formed in the highest amount with the highest affinity for all AChBPs. Finally, azides 28-37 were mixed with alkynes in the presence of $L s \mathrm{AChBP}$ for 10 days. Analysis revealed that $\mathbf{4 0}$ was formed in the greatest amount, thus demonstrating that $L s \mathrm{AChBP}$ can catalyze the formation of the highest affinity product from a bulk of various azides and alkynes present in the reaction mixture, analogously to the AChE system. All in situ click chemistry experiments with AChBPs included BSA control reaction which exhibited no product formation. Crystal structure of triazole 40 in complex with Ac AChBP confirmed a bound conformation, and a pose predicted from previously seen conformations of quaternary amines that bind to nAChRs through cation-quadrupole interactions involving $\pi$-electron-rich aromatic side chains (e.g., tryptophan). ${ }^{128}$ Triazole moiety forms a hydrogen bond with a neighbouring water molecule which again suggests that precursors in in situ click chemistry drive a conformation preferred by the triazole product rather than accommodating a conformation of the free protein, a fact previously reported for the AChE system.

\section{4. DNA Minor Groove Templation Role}

The templation potential of in situ click chemistry can be expanded to the minor groove of double-helical DNA, as shown by Poulien-Kerstien and Dervan ${ }^{129}$ and more recently by Imoto et al. ${ }^{130}$ In their pioneer work, Poulien-Kerstien and Dervan explored the Huisgen's cycloaddition to link two aromatic-substituted hairpin polyamides capable of sequence-specific binding to DNA in the DNA-templated reaction. Polyamides composed of three aromatic amino acids, $N$-metylpyrrole (Py), $N$ methylimidazole (Im), and $N$-methyl-3-hydroxypyrrole, distinguish four Watson-Crick base pairs by a set of pairing rules and represent a potential way to modulate transcription. ${ }^{131}$ Longer binding-site size is considered to be crucial for application in gene regulation since longer sequences should occur less frequently in genome leading to the development of various polyamide motifs for selective targeting. ${ }^{132,133}$ The most promising strategy came from chemical ligation of two hairpin polyamides to form dimers. ${ }^{134,135}$ However, though having an excellent affinity and specificity to 10 base pair (bp) DNA sequences, hairpin dimers lack the cell and nuclear uptake properties of smaller hairpins, apparently due to size and shape. ${ }^{136}$ Sixring hairpin polyamides with alkyne $\mathbf{4 2 a}$ and $\mathbf{4 2 b}$ or azide 43a and 43b moieties with different linker lengths were designed so that their matching sites are adjacent on the DNA, which allows the formation of hairpin dimers in si$t u$ (Fig. 16). ${ }^{137-140}$

Experiments were carried out at $37{ }^{\circ} \mathrm{C}$ at $\mathrm{pH} 7.0$ with equimolar concentrations of one azide, one alkyne and DNA duplex $\mathrm{A}(1 \mu \mathrm{M})$. When any pair of hairpin polyamides $(42 a+43 a, 42 a+43 b, 42 b+43 a, 42 b+43 b)$ was combined in solution, HPLC analysis of the reaction mixtures (verified using matrix-assisted laser desorption/ionization-time of flight mass spectrometry) revealed significant acceleration of formation of hairpin dimers in the presence of DNA template with respect to the nontemplated reaction between 42a and 43a. The rate of dimer formation from 42a and 43b was slower than the rate of formation from 42a and 43a, presumably due to the additional flexibility in the linker of $\mathbf{4 3 b}$, which allows the reactants to more freely adopt nonproductive conformation. Also, the rate of product formation from pairings of 42b with 43a and 43b is decreased due to the differences in the reactivity between $\mathbf{4 2} \mathbf{a}$, activated with an electron withdrawing group (EWG), and EWG-free alkyne 42b. Moreover, when the alkynyl reactant is substituted with an EWG, stereoelectronics of the reaction pathway favoured formation of 1,4-regioisomer. ${ }^{141}$ Thermal reaction between 42a and 43a or 43b afforded predominantly the 1,4regioisomeric products, while DNA-templated reactions afforded them exclusively. When the EWG-free alkyne 42b was paired with either 43a or 43b, each thermal reaction produced two corresponding regioisomers in a ratio of 1:1, while DNA-templated reaction produced only a single isomer $(\mathbf{4 2 b}+\mathbf{4 3 a})$ or a ratio of 3:1 $(\mathbf{4 2 b}+\mathbf{4 3 b})$. 


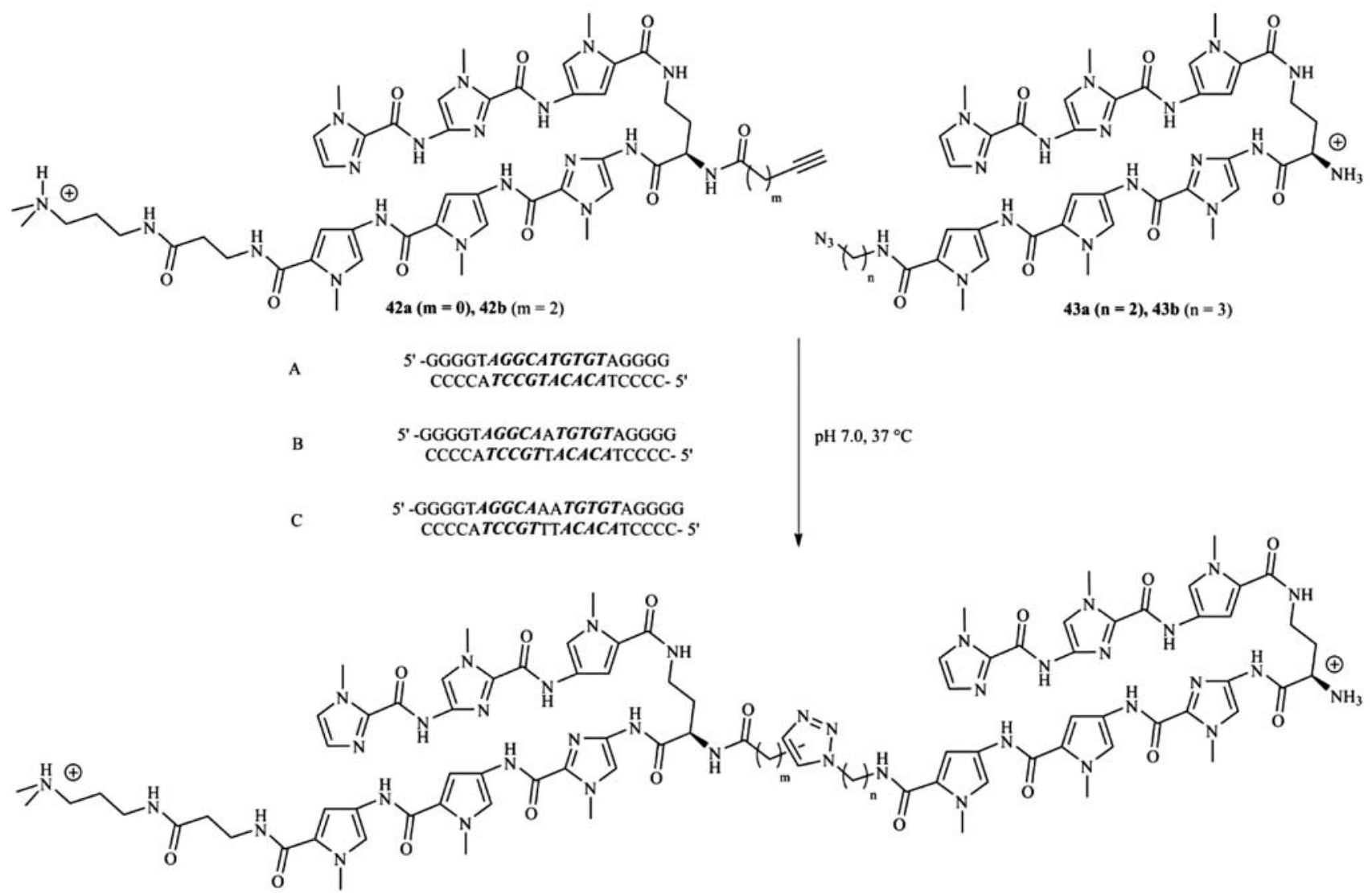

Figure 16. DNA-templated dimerization of hairpin polyamides on DNA duplexes with hairpin binding sites separated with zero (A), one (B), or two (C) base pairs. ${ }^{130}$

DNA-templated cycloadditions were found to be sensitive upon separation of the hairpin-binding sites with additional bp. Thus, upon insertion of one bp between two adjacent five bp hairpin-binding sites for the hairpin polyamides 42a,b and 43a,b (DNA duplex B), the only product formed from $\mathbf{4 2 b}$ and $\mathbf{4 3 b}$ was detected with about $50 \%$ yield. When two intervening bp were inserted (DNA duplex C), no product was detected using various pairs of hairpin polyamides. DNA-templated cycloadditions were also found to be sensitive upon DNA sequence of the two hairpin-binding sites, as illustrated by the mismatch tolerance study of optimal pair 42a and 43a. When a single bp mismatch is present under azide hairpin polyamide-binding or under each of the two harpin-binding sites, the rate of the hairpin dimer-forming cycloaddition is nearly halved or lowered over 2.5 fold, respectively. However, when the concentration of reacting hairpins 42a and 43a was varied from $1 \mu \mathrm{M}$ to $0.5 \mu \mathrm{M}$, a threshold concentration that defined the ability of hairpins to distinguish between match site and double bp mismatch site was detected somewhere between $1 \mu \mathrm{M}$ and $0.75 \mu \mathrm{M}$. The authors suggested that, at some lower concentration, an additional threshold exists that allows hairpins to distinguish the match site from a single bp mismatch site, rendering the possibility to increase the ratio of hairpin dimer formation on match over mismatch DNA and the overall hairpin dimer yield.

Recently, Di Antonio et al. have demonstrated the ability of the in situ click chemistry multicomponent approach to identify potent and selective small molecules binding a region of chromosomes formed by guanine-rich sequences of DNA called G-quadruplex (G4) ${ }^{142}$ In their study, they selected G4 formed by the human telomeric DNA (H-Telo). ${ }^{143}$ No adduct was formed when the reaction mixture was incubated in the absence of DNA, in the presence of double-stranded DNA, or in the presence of telomeric oligonucleotides pre-annealed to prevent G4 formation, thus confirming that H-Telo serves as a reaction pot. Moreover, adducts obtained from a reaction conducted in the presence of RNA G4-structure demonstrated selective RNA versus DNA G4 structure binding. More recently, Glassford et al. have expanded the templation potential of the in situ click chemistry to E. coli 70 S ribosomes or their 50S subunits and thus synthesized potent macrolide antibiotics that target bacterial ribosome. ${ }^{144} \mathrm{Al}-$ so, the in situ click chemistry approach has been applied to explore the conformational space of the ligand binding site of a M. tuberculoisis transcriptional repressor EthR which regulates the transcription of monooxygenase EthA and thus controls the sensitivity of M. tuberculoisis to an- 
tibiotic ethionamide. The in situ formed inhibitor, displayed 10-fold higher activity than the starting azide, and induced a significant conformational change of the ligand-binding domain of EthR. ${ }^{145}$

\section{Iterative in situ Click Chemistry}

In addition to the development of coupled bivalent enzyme inhibitors targeting the active site, in situ click chemistry can produce multivalent ligands active on protein surface, such as allosteric, interfacial, or non-functional surface sites. Once a bivalent ligand has been formed via in situ approach from the corresponding azide and alkyne building blocks, that biligand can serve as an anchor ligand for the identification of a triligand, and so forth, in a so-called iterative in situ click chemistry approach. This approach has been successfully introduced by Agnew et al. to identify a triligand antibody-like capture agent against human or bovine CA-II (h(b)CA-II) (Fig. 17). ${ }^{146}$

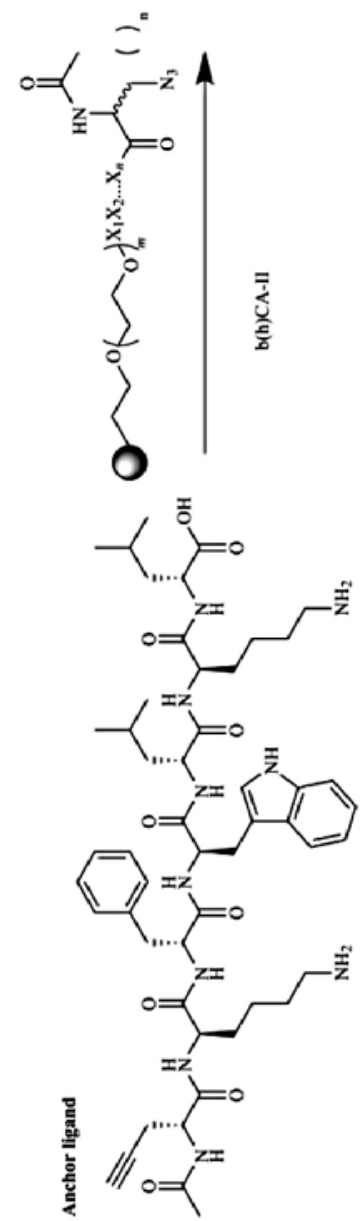

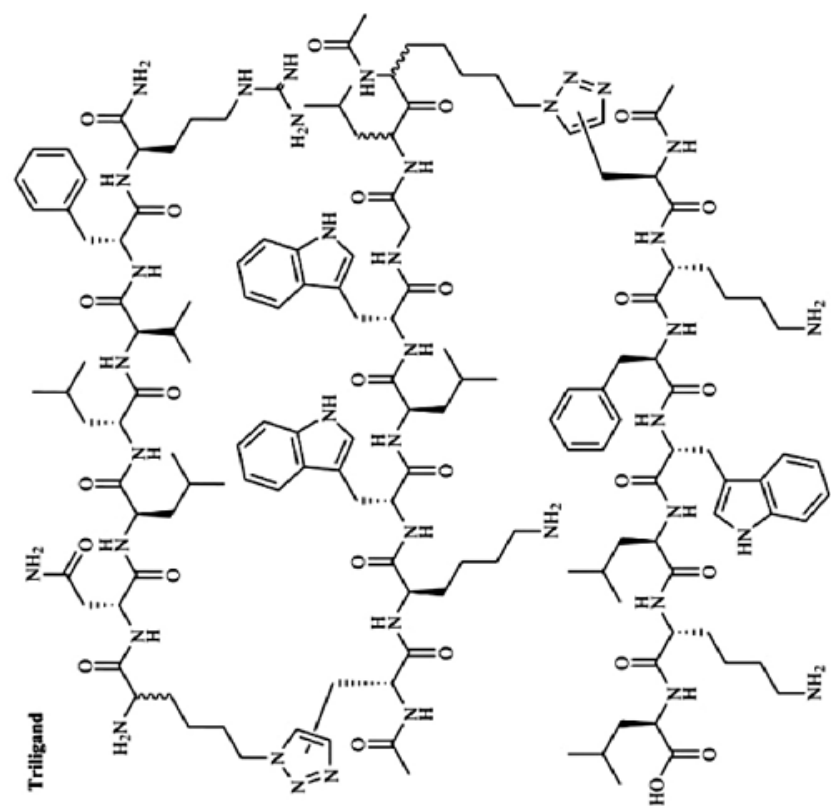
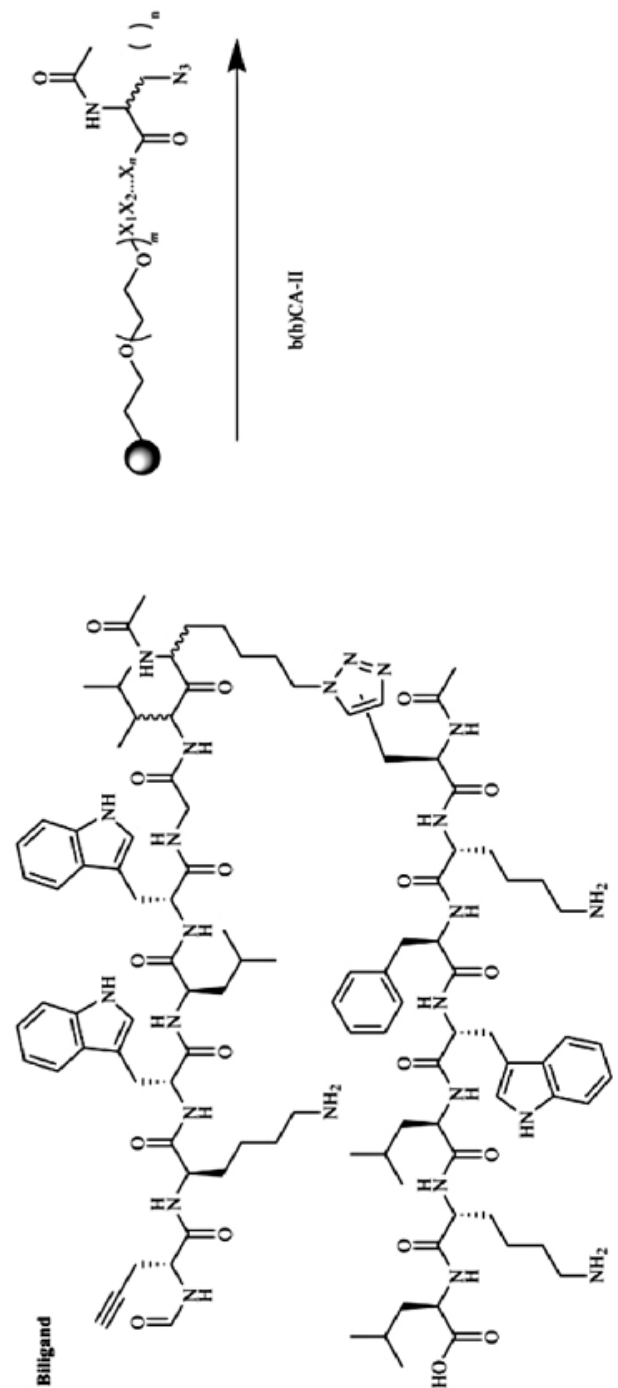

Figure 17. Iterative in situ click chemistry approach for developing triligand capture agent for human or bovine carbonic anhydrase II (b(h)CA-II). ${ }^{146}$ 


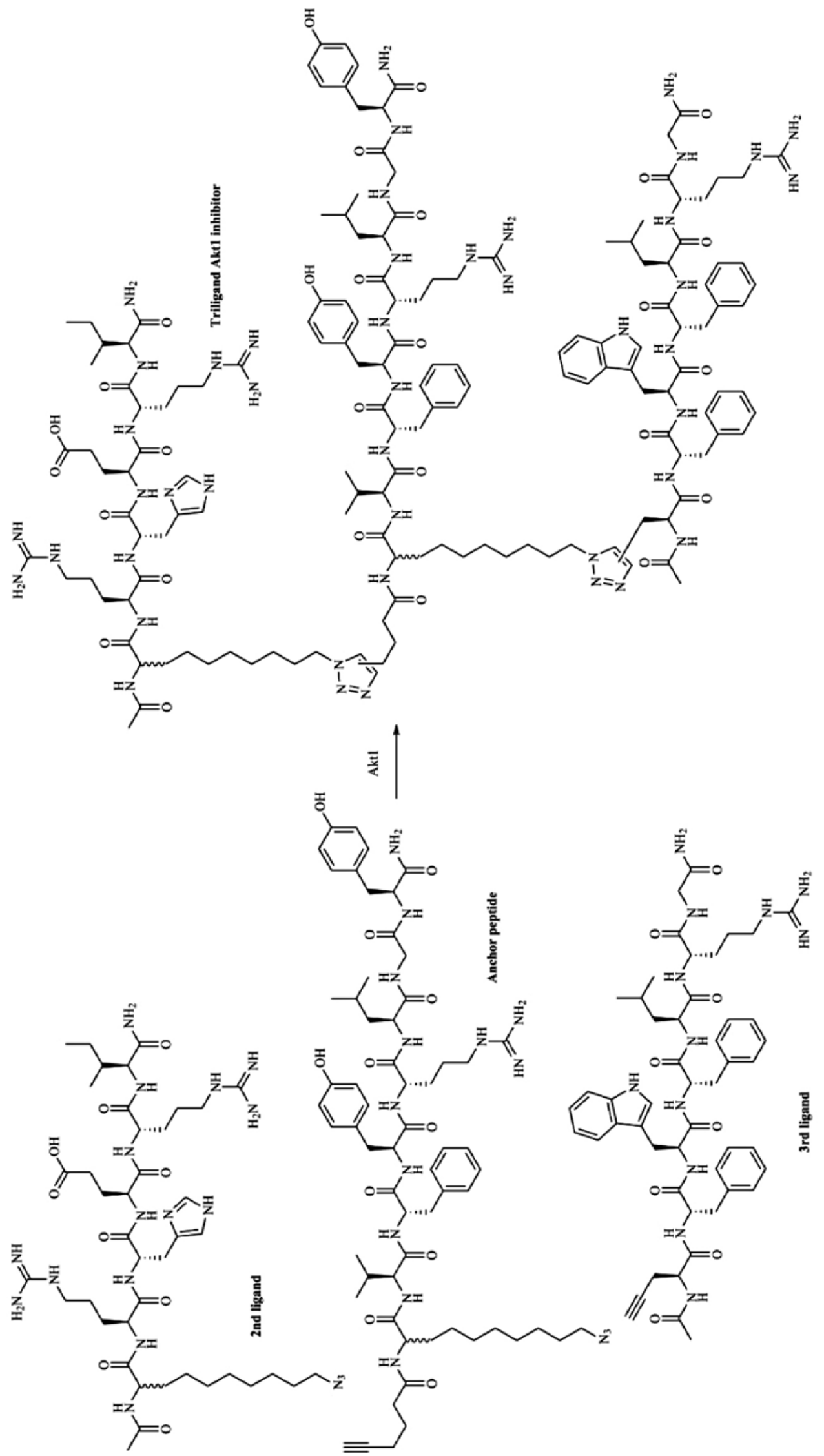

Figure 18. In situ click chemistry approach for developing triligand capture agent/inhibitor for Akt1 kinase. ${ }^{150}$ 
The first anchor ligand was identified by screening a comprehensive one-bead-one-compound (OBOC) peptide library consisting of short chain peptides, against fluorescently labelled bCA-II. ${ }^{147,148}$ Analysis of the position-dependent frequency of amino acids identified the anchor ligand, a short heptapeptide comprised of non-natural Damino acids and a terminal, acetylene-containing amino acid D-propargylglycine (D-Pra), showing an approximately $500 \mu \mathrm{M}$ affinity for bCA-II. This anchor ligand was used in the second screen against the OBOC peptide library, in which peptides were modified with an azide linker, in the presence of bCA-II to identify the triazole product showing a $3 \mu \mathrm{M}$ binding affinity for bCA-II. The screen was repeated with this terminal D-Pra-containing biligand as the new anchor unit to identify a triligand, which exhibited strong binding affinities against bCA-II $(64 \mathrm{nM})$ and hCA-II $(45 \mathrm{nM})$. However, no regioselectivity was observed for the two triazoles in the triazole capture agent. On-bead, protein-templated triligand formation was confirmed by an enzyme-linked colorimetric assay containing a biotin conjugate of the biligand anchor. ${ }^{149}$ The triligand was only formed in the presence of b(h)CA-II, and not when b(h)CA-II was absent or other proteins (transferrin, BSA) used instead. Similarly, onbead, protein-templated formation was not observed when the incorrect biligand anchor was used. The triligand did not interfere with bCA-II intrinsic esterase activity, which indicated that it binds away from the active site.

The strategy described was also applied to identify a high-specificity, triligand capture agent/inhibitor for Akt1 kinase. ${ }^{150}$ Akt1 kinase is responsible for signal transduction from the plasma membrane to downstream effector molecules that control cell growth, apoptosis, and translation. ${ }^{151}$ To ensure the development of an allosteric site inhibitor, Millward et al. carried out an initial screen against a large OBOC peptide library on a kinase preinhibited with an ATP-competitive inhibitor, Ac7. ${ }^{150}$ One of the $N$ terminal azido-amino acid-containing peptides generated in the initial screen showed almost 95\% inhibition of the Akt1 kinase in the absence and presence of the conjugated small molecule inhibitor and was therefore employed as an anchor for biligand development (Fig. 18).

The most promising candidate from biligand screens was modified with 5-hexynoic acid at the $\mathrm{N}$-terminus and used as an anchor ligand for triligand development which finally resulted in the tertiary peptide containing two triazole moieties. An analytical assay based on immune$\mathrm{PCR}^{152}$ revealed that the click reaction between the onbead secondary peptide and the soluble anchor peptide was approximately 10 -fold more efficient in the presence of Akt1 than in its absence, confirming the requirement for the target protein to template the click reaction. The biligand showed 100-fold improvement in its affinity for Akt relative to the anchor peptide, while the triligand showed 2-3 fold affinity gain for Akt1 $\left(K_{\mathrm{d}}=200 \mathrm{nM}\right)$. The specificity characterization of the anchor, biligand, and triligand for a panel of His-tagged protein kinases revealed that the anchor was very specific for the Akt1 protein, with only modest cross-reactivity to GSK $3 \beta$ protein kinase. The biligand showed reduced specificity, with significant binding to GSK $3 \beta$. For the triligand, binding to GSK3 $\beta$ was reduced to the level observed for the anchor peptide. These observations indicate that large improvements in affinity may come at the expense of reduced specificity, whereas increased specificity is not necessarily accompanied by increased affinity. This inverse correlation between affinity and selectivity is in accordance with previous studies on small molecule protein kinase inhibitors, ${ }^{153}$ antibody-small molecule interactions, ${ }^{154}$ DNA-protein interactions, ${ }^{155}$ and protein-protein interactions. ${ }^{156}$ Measuring Akt1 kinase activity under varying substrate and triligand concentrations eliminated the possibility of a competitive mode of Akt1 inhibition by the triligand with respect to ATP and peptide substrates. ${ }^{150}$ This confirmed that the triligand binds to a location away from the active site of the kinase and that inhibition occurs $v i a$ an allosteric mechanism. Finally, the anchor, biligand, and triligand were tested for the ability to recognize Akt from the ovarian cancer cell line OVCAR3 in immunoprecipitation (IP) experiments. IP experiments confirmed the increased affinity of the biligand relative to the anchor peptide in OVCAR3 cell lysates from both cells stimulated with a combination of epidermal growth factor (EGF) and insulin and from untreated control cells. The triligand showed somewhat increased IP of Akt relative to the biligand only in lysates from induced cells. However, an analysis of the total IP protein by SDS-PAGE electrophoresis showed low non-selective binding for all ligands. The authors observed IP of the protein that likely corresponds to the GSK3 $\beta$ kinase by the triligand, and to a lesser degree, by the anchor and the biligand. ${ }^{150}$ The underlying rationale for GSK3 binding to ligands is yet to be explained. However, IP experiments confirm the increase in capture efficiency of ligands, particularly in stimulated cells, as they are being translated from anchor to triligand with their affinity and selectivity criteria increased.

\section{Conclusion}

Receptor-based combinatorial chemistry is a promising strategy developed for identifying possible leads in drug discovery whereby the biomolecular target of interest is used to "fish out" building blocks that couple into high affinity compounds. Theoretical studies have shown that, unless excessive amounts of a molecular target are used, high affinity compounds have a high probability of being significantly amplified over other possible combinations of building blocks. Also, any significantly amplified compound is guaranteed to be a high affinity compound.

The examples listed in this review have illustrated the potential of various receptor-based combinatorial che- 
mistry approaches to identify high affinity compounds and, in some occasions, their potential to elucidate the binding modes of substrates to their biomolecular target.

The in situ click chemistry approach combines building blocks through 1,3-dipolar cycloaddition of azides and alkynes (Huisgen's cycloaddition). This approach is predominantly used for the discovery of enzyme inhibitors targeting enzyme active sites as illustrated with examples from the AChE system, although the templation potential of this approach can be extended to more flexible intersubunit binding sites and even minor groove of double-helical DNA. Examples from AChE and AChBP systems have shown that in situ click chemistry allows one to freeze in-frame conformations that associate with high-affinity inhibitors and are normally not detected by conventional structural methods. These findings set out a stage for developing unusual strategies of drug design where the most selective compounds would induce distinctive conformations of the target.

More efficient and synergistic approaches that combine receptor based combinatorial chemistry with in silico methods such as de novo structure based design (SBD) or molecular docking studies limit the selection of the coupling partners that have to be incubated with protein target to the ones based on retrosynthesis of in silico designed hits thus indicating that the full potential of receptor based combinatorial chemistry in drug discovery is yet to be discovered. ${ }^{157,158}$

\section{Acknowledgements}

This work was supported by the Croatian Science Foundation (Grant HRZZ 4307 PI: Z. Kovarik).

\section{References}

1. R. S. Bohacek, C. McMartin, W. C. Guida, Med. Res. Rev., 1996, 16, 3-50.

https://doi.org/10.1002/(SICI)1098-1128(199601)16:1<3: :AID-MED1>3.0.CO;2-6

2. H. N. Weller, D. S. Nirschl, E. W. Petrillo, M. A. Poss, C. J. Andres, C. L. Cavallaro, M. M. Echols, K. A. Grant-Young, J. G. Houston, A. V. Miller, R. T. Swann, J. Comb. Chem., 2006, 8, 664-669. https://doi.org/10.1021/cc050164h

3. St.L. Dixon, H. O. Villar, J. Chem. Inf. Comp. Sci., 1998, 38, 1192-1203. https://doi.org/10.1021/ci980105+

4. J. D. Cheeseman, A. D. Corbett, J. L. Gleason, R. J. Kazlauskas, Chem. Eur. J., 2005, 11, 1708-1716. https://doi.org/10.1002/chem.200400371

5. R. Huisgen, G. Szeimies, L. Moebius, Chem. Ber., 1967, 100, 2494-2507. https://doi.org/10.1002/cber.19671000806

6. R. Huisgen, In: 1,3-Dipolar cycloaddition - introduction, survey, mechanism., A. Padwa, Ed., Wiley: New York, 1984, Vol. 1, pp. 1-176.
7. P. T. Corbett, J. Leclaire, L. Vial, K. R. West, J.-L. Wietor, J. K. M. Sanders, S. Otto, Chem. Rev., 2006, 106, 3652-3711. https://doi.org/10.1021/cr020452p

8. M. Mondal, A. K. Hirsch, Chem. Soc. Rev., 2015, 44, 24552488. https://doi.org/10.1039/C4CS00493K

9. Y. Kubota, S. Sakamoto, K. Yamaguchi, M. Fujita, Proc. Natl. Acad. Sci. USA, 2002, 99, 4854-4856. https://doi.org/10.1073/pnas.082643499

10. M. S. Congreve, D. J. Davis, L. Devine, C. Granata, M. O'Reilly, P. G. Wyatt, H. Jhoti, Angew. Chem., Int. Ed., 2003, 42, 4479-4482. https://doi.org/10.1002/anie.200351951

11. S. Otto, J. Mater. Chem., 2005, 15, 3357-3361. https://doi.org/10.1039/b500703h

12. A. V. Eliseev, M. I. Nelen, Chem. Eur. J., 1998, 4, 825-834. https://doi.org/10.1002/(SICI)1521-3765(19980515)4:5 $<825:$ :AID-CHEM825>3.0.CO;2-7

13. J. S. Moore, N. W. Zimmerman, Org. Lett., 2000, 2, 915918. https://doi.org/10.1021/ol0055723

14. Z. Grote, R. Scopelliti, K. Severin, Angew. Chem., Int. Ed., 2003, 42, 3821-3825. https://doi.org/10.1002/anie.200351623

15. P. T. Corbett, S. Otto, J. K. M. Sanders, Chem. Eur. J., 2004, 10, 3139-3143. https://doi.org/10.1002/chem.200400300

16. K. Severin, Chem. Eur. J., 2004, 10, 2565-2580. https://doi.org/10.1002/chem.200305660

17. J.-M. Lehn, R. A. Woods, D. H. Bartón, J. E. Corrie, D. A. Widdowson, Chem. Eur. J., 1977, 5, 2455-2463. https://doi.org/10.1002/(SICI)1521-3765(19990903)5:9 $<2455$ ::AID-CHEM2455>3.0.CO;2-H

18. S. J. Rowan, S. J. Cantrill, G. R. L. Cousins, J. K. M. Sanders, J. F. Stoddart, Angew. Chem., Int. Ed., 2002, 41, 899- 952. https://doi.org/10.1002/1521-3773(20020503)41:9<1460: :AID-ANIE11111460>3.0.CO;2-N

19. I. Huc, J.-M. Lehn, Proc. Natl. Acad. Sci. USA, 1997, 94 , 2106-2110. https://doi.org/10.1073/pnas.94.6.2106

20. M. Hochgürtel, R. Biesinger, H. Kroth, D. Piecha, M. W. Hofmann, S. Krause, O. Schaaf, C. Nicolau, A. V. Eliseev, J. Med. Chem., 2003, 46, 356-358. https://doi.org/10.1021/jm025589m

21. O. Ramström, S. Lohmann, T. Bunyapaiboonsri, J.-M. Lehn, Chem. Eur. J., 2004, 10, 1711-1715. https://doi.org/10.1002/chem.200305551

22. M. Sindelar, K. T. Wanner, ChemMedChem, 2012, 7, 16781690. https://doi.org/10.1002/cmdc.201200201

23. N. Nazarpack-Kandlousy, J. Zweigenbaum, J. Henion, A.V. Eliseev, J. Comb. Chem., 1999, 1, 199-206. https://doi.org/10.1021/cc980036b

24. B. Shi, R. Stevenson, D. J. Campopiano, M. F. Greaney, J. Am. Chem. Soc., 2006, 128, 8459-8467. https://doi.org/10.1021/ja058049y

25. O. Ramström, J.-M. Lehn, Chem. Bio. Chem., 2000, 1, 41- 48. https://doi.org/10.1002/1439-7633(20000703)1:1<41::AIDCBIC41>3.0.CO;2-L

26. L. Milanesi, C.A. Hunter, S.E. Sedelnikova, J.P. Waltho, D. A. Widdowson, Chem. Eur. J., 2006, 12, 1081-1087. https://doi.org/10.1002/chem.200500357 
27. E. C. Y. Woon, M. Demetriades, E. A. L. Bagg, W. Aik, S. M. Krylova, J. H. Y. Ma, M. Chan, L. J. Walport, D. W. Wegman, K. N. Dack, M. A. McDonough, S. N. Krylov, C. J. Schofield, J. Med. Chem., 2012, 55, 2173-2184. https://doi.org/10.1021/jm201417e

28. C. Saiz, V. Castillo, P. Fontán, M. Bonilla, G. Salinas, A. Rodríguez-Haralambides, S. G. Mahler, Mol. Diversity, 2014, 18, 1-12. https://doi.org/10.1007/s11030-013-9485-3

29. S.-A. Poulsen, L.F. Bornaghi, Bioorg. Med. Chem., 2006, 14, 3275-3284. https://doi.org/10.1016/j.bmc.2005.12.054

30. P. K. Mehta, P. Christen, Adv. Enzymol. Relat. Areas Mol., 2000, 74, 129-184.

31. K. M. El-Mahdy, A. M. El-Kazak, M. Abdel-Megid, M. Seada1, O. Farouk, Acta Chim. Slov. 2016, 63, 18-25. https://doi.org/10.17344/acsi.2015.1555

32. Z. Fang, W. He, X. Li, Z. Li, B. Chen, P. Ouyang, K. Guo, Bioorg. Med. Chem. Lett., 2013, 23, 5174-5177. https://doi.org/10.1016/j.bmcl.2013.07.011

33. H. Lis, N. Sharon, Chem. Rev., 1998, 98, 637-674. https://doi.org/10.1021/cr940413g

34. N. R. Rose, E. C. Y. Woon, G. L. Kingham, O. N. F. King, J. Mecinović, I. J. Clifton, S. S. Ng, J. Talib-Hardy, U. Oppermann, M. A. McDonough, C. J. Schofield, J. Med. Chem., 2010, 53, 1810-1818. https://doi.org/10.1021/jm901680b

35. A. J. Clipson, V. T. Bhat, I. McNae, A. M. Caniard, D. J. Campopiano, M. F. Greaney, Chem. - Eur. J., 2012, 18, 10562-10570. https://doi.org/10.1002/chem.201201507

36. V. T. Bhat, A. M. Caniard, T. Luksch, R. Brenk, D. J. Campopiano, M. F. Greaney, Nat. Chem., 2010, 2, 490-497. https://doi.org/10.1038/nchem.658

37. B. Shi, M. F. Greaney, Chem. Commun., 2005, 7, 886-888. https://doi.org/10.1039/b414300k

38. C. Andersson, E. Mosialou, A. E. Adang, G. J. Mulder, A. van Der Gen, R. Morgenstern, J. Biol. Chem., 1991, 266, 2076-2079.

39. R. M. F. Cardoso, D. S. Daniels, C. M. Bruns, J. A. Tainer, Proteins, 2003, 51, 137-146. https://doi.org/10.1002/prot.10345

40. H. Xiangdong, R. Manetsch, Chem. Soc. Rev., 2010, 39 , 1316-1324. https://doi.org/10.1039/b904092g

41. H. C. Kolb, M. G. Finn, K. B. Sharpless, Angew. Chem., Int. Ed., 2001, 40, 2004-2021.

https://doi.org/10.1002/1521-3773(20010601)40:11<2004: :AID-ANIE2004>3.0.CO;2-5

42. H. C. Kolb, K. B. Sharpless, Drug Discovery Today, 2003, 8, 1128-1137. https://doi.org/10.1016/S1359-6446(03)02933-7

43. K. B. Sharpless, R. Manetsch, Expert Opin. Drug Discovery, 2006, 1, 525-538. https://doi.org/10.1517/17460441.1.6.525

44. J. Inglese, S. J. Benkovic, Tetrahedron, 1991, 47, 23512364. https://doi.org/10.1016/S0040-4020(01)81773-7

45. S. E. Greasley, T. H. Marsilje, H. Cai, S. Baker, S. J. Benkovic, D. L. Boger, I. A. Wilson, Biochemistry, 2001, 40, 13538-13547. https://doi.org/10.1021/bi011482+

46. Y. Yu, L. Ye, K. Haupt, K. Mosbach, Angew. Chem., Int. Ed., 2002, 41, 4459-4463. https://doi.org/10.1002/1521-3773(20021202)41:23<4459: :AID-ANIE4459>3.0.CO;2-2

47. R. Nguyen, I. Huc, Angew. Chem., Int. Ed., 2001, 40, 1774-1776.

https://doi.org/10.1002/1521-3773(20010504)40:9<1774: :AID-ANIE17740>3.0.CO;2-G

48. T. Maki, A. Kawamura, N. Kato, J. Ohkanda, Mol. Biosyst., 2013, 9, 940-943.

https://doi.org/10.1039/C2MB25388G

49. E. Oueis, F. Nachon, C. Sabot, P.-Y. Renard, Chem. Commun., 2014, 50, 2043-2045. https://doi.org/10.1039/c3cc48871c

50. T. Asaba, T. Suzuki, R. Ueda, H. Tsumoto, H. Nakagawa, N. Miyata, J. Am. Chem. Soc., 2009, 131, 6989-6996. https://doi.org/10.1021/ja807083y

51. S. S. Kulkarni, X. Hu, K. Doi, H.-G. Wang, R. Manetsch, ACS Chem. Biol., 2011, 6, 724-732. https://doi.org/10.1021/cb200085q

52. N. K. Namelikonda, R. Manetsch, Chem. Commun., 2012, 48, 1526-1528. https://doi.org/10.1039/C1CC14724B

53. A. M. Cappalonga Bunn, R. S. Alexander, D. W. Christianson, J. Am. Chem. Soc., 1994, 116, 5063-5068. https://doi.org/10.1021/ja00091a006

54. G. S. Ponticello, M. B. Freedman, C. N. Habecker, P. A. Lyle, H. Schwam, S. L. Varga, M. E. Christy, W. C. Randall, J. J. Baldwin, J. Med. Chem., 1987, 30, 591-597. https://doi.org/10.1021/jm00387a002

55. J. A. Wells, C. L. McClendon, Nature, 2007, 450, 10011009. https://doi.org/10.1038/nature06526

56. N. N. Danial, S. J. Korsmeyer, Cell, 2004, 116, 205-219. https://doi.org/10.1016/S0092-8674(04)00046-7

57. T. Oltersdorf, S. W. Elmore, A. R. Shoemaker, R. C. Armstrong, D. J. Augeri, B. A. Belli, M. Bruncko, T. L. Deckwerth, J. Dinges, P. J. Hajduk, M. K. Joseph, S. Kitada, S. J. Korsmeyer, A. R. Kunzer, A. Letai, C. Li, M. J. Mitten, D. G. Nettesheim, S. C. Ng, P. M. Nimmer, J. M. O'Connor, A. Oleksijew, A. M. Petros, J. C. Reed, W. Shen, S. K. Tahir, C. B. Thompson, K. J. Tomaselli, B. L. Wang, M. D. Wendt, H. C. Zhang, S. W. Fesik, S. H. Rosenberg, Nature, 2005, 435, 677-681. https://doi.org/10.1038/nature03579

58. M. D. Wendt, W. Shen, A. Kunzer, W. J. McClellan, M. Bruncko, T. K. Oost, H. Ding, M. K. Joseph, H. C. Zhang, P. M. Nimmer, S. C. Ng, A. R. Shoemaker, A. M. Petros, A. Oleksijew, K. Marsh, J. Bauch, T. Oltersdorf, B. A. Belli, D. Martineau, S. W. Fesik, S. H. Rosenberg, S. W. Elmore, J. Med. Chem., 2006, 49, 1165-1181. https://doi.org/10.1021/jm050754u

59. A. M. Petros, J. Dinges, D. J. Augeri, S. A. Baumeister, D. A. Betebenner, M. G. Bures, S. W. Elmore, P. J. Hajduk, M. K. Joseph, S. K. Landis, D. G. Nettesheim, S. H. Rosenberg, W. Shen, S. Thomas, X. L. Wang, I. Zanze, H. C. Zhang, S. W. Fesik, J. Med. Chem., 2006, 49, 656-663. https://doi.org/10.1021/jm0507532

60. X. Hu, J. Sun, H.-G. Wang, R. Manetsch, J. Am. Chem. Soc., 2008, 130, 13820-13821. https://doi.org/10.1021/ja802683u 
61. C. E. Hoyle, A. B. Lowe, C. N. Bowman, Chem. Soc. Rev., 2010, 39, 1355-1387. https://doi.org/10.1039/b901979k

62. W. R. Dichtel, O. S. Miljanic, J. M. Spruell, J. R. Heath, J. F. Stoddart, J. Am. Chem. Soc., 2006, 128, 10388-10390. https://doi.org/10.1021/ja063127i

63. R. L. Weller, S. R. Rajski, Org. Lett., 2005, 7, 2141-2144. https://doi.org/10.1021/ol0504749

64. P. Wu, A. Feldman, A. K. Nugent, C. J. Hawker, A. Scheel, B. Voit, J. Pyun, J. M. J. Fréchet, K. B. Sharpless, V. V. Fokin, Angew. Chem., Int. Ed., 2004, 43, 3928-3932. https://doi.org/10.1002/anie.200454078

65. A. J. Link, M. K. S. Wink, D. A. Tirrell, J. Am. Chem. Soc., 2004, 126, 10598-10602. https://doi.org/10.1021/ja047629c

66. N. J. Agard, J. A. Prescher, C. R. Bertozzi, J. Am. Chem. Soc., 2004, 126, 15046-15047. https://doi.org/10.1021/ja044996f

67. Q. Wang, T. R. Chan, R. Hilgraf, V. V. Fokin, K. B. Sharpless, M. G. Finn, J. Am. Chem. Soc., 2003, 125, 3192-3193. https://doi.org/10.1021/ja021381e

68. D. C. Rees, M. Congreve, C. V. Murray, R. Carr, Nat. Rev. Drug Discov., 2004, 3, 660-672. https://doi.org/10.1038/nrd1467

69. D. A. Erlanson, R. S. McDowell, T. O'Brien, J. Med. Chem., 2004, 47, 3463-3482. https://doi.org/10.1021/jm040031v

70. D. A. Erlanson, S. K. Hansen, Curr. Opin. Chem. Biol., 2004, 8, 399-406. https://doi.org/10.1016/j.cbpa.2004.06.010

71. R. Carr, M. Congreve, C. V. Murray, D. C. Rees, Drug Discov. Today, 2005, 10, 987-992. https://doi.org/10.1016/S1359-6446(05)03511-7

72. D. Das, T. Chanda, L. Rokhum, Acta Chim. Slov., 2015, 62, 775-783.

73. S. B. Shuker, P. J. Hajduk, R. P. Meadows, S. V. Fesik, Science, 1996, 274, 1531-1534. https://doi.org/10.1126/science.274.5292.1531

74. A. Schuffenhauer, S. Ruedisser, A. Marzinzik, W. Jahnke, P. Selzer, E. Jacoby, Curr. Top. Med. Chem., 2005, 5, 751-762. https://doi.org/10.2174/1568026054637700

75. 63M. J. Hartshorn, C. V. Murray, A. Cleasby, M. Frederickson, I. J. Tickle, H. Jhoti, J. Med. Chem., 2005, 48, 403-413.

76. J. R. Huth, C. Sun, Comb. Chem. High Throughput Screening, 2002, 5, 631-643. https://doi.org/10.2174/1386207023329941

77. M. Mammen, S. K. Chio, G. M. Whitesides, Angew. Chem., Int. Ed., 1998, 37, 2755-2794.

https://doi.org/10.1002/(SICI)1521-3773(19981102)37:20 $<2754:$ :AID-ANIE2754>3.0.CO;2-3

78. O. Ramström, J.-M. Lehn, Nat. Rev. Drug Discov., 2002, 1, 26-36. https://doi.org/10.1038/nrd704

79. S. Otto, R. L. E. Furlan, J. K. M. Snaders, Drug Discov. Today, 2002, 7, 117-125.

https://doi.org/10.1016/S1359-6446(02)00006-5

80. B. Debruin, P. Hauwert, J. N. H. Reek, Angew. Chem., Int. Ed., 2006, 45, 2660-2663. https://doi.org/10.1002/anie.200504480

81. A. Valade, D. Urban, J. M. Beau, ChemBioChem, 2006, 7, 1023-1027. https://doi.org/10.1002/cbic.200600022

82. V. V. Rostovtsev, L. G. Green, V. V. Fokin, K. B. Sharpless, Angew. Chem., Int. Ed., 2002, 41, 2596-2599.

https://doi.org/10.1002/1521-3773(20020715)41:14<2596: :AID-ANIE2596>3.0.CO;2-4

83. C. W. Tornøe, C. Christensen, M. Meldal, J. Org. Chem., 2002, 67, 3057-3064. https://doi.org/10.1021/jo011148j

84. A. Krasinski, V. V. Fokin, K. B. Sharpless, Org. Lett., 2004, 6, 1237-1240. https://doi.org/10.1021/ol0499203

85. L. Zhang, X. Chen, P. Xue, H. H. Y. Sun, I. D. Williams, K. B. Sharpless, V. V. Fokin, G. Jia, J. Am. Chem. Soc., 2005, 127, 15998-15999. https://doi.org/10.1021/ja054114s

86. J. Albadi, A. Alihosseinzadeh, A. Mansournezhad, Acta Chim. Slov., 2015, 62, 617-624. https://doi.org/10.17344/acsi.2014.1211

87. D. L. Boger, N. E. Haynes, P. A. Kitos, M. S. Warren, J. Ramcharan, A. E. Marolewski, S. J. Benkovic, Bioorg. Med. Chem., 1997, 5, 1817-1830.

https://doi.org/10.1016/S0968-0896(97)00120-X

88. D. Rideout, Science, 1986, 233, 561-563. https://doi.org/10.1126/science.3523757

89. W. L. Mock, T. A. Irra, J. P. Wepsoec, M. Adhya, J. Org. Chem., 1989, 54, 5302-5308.

https://doi.org/10.1021/jo00283a024

90. D. Makuc, T. Merckx, W. Dehaen, J. Plavec, Acta Chim. Slov., 2016, 63, 484-488.

https://doi.org/10.17344/acsi.2016.2251

91. W. G. Lewis, L. G. Green, F. Grynszpan, Z. Radić, P. R. Carlier, P. Taylor, M. G. Finn, K. B. Sharpless, Angew. Chem., Int. Ed., 2002, 41, 1053-1057.

https://doi.org/10.1002/1521-3773(20020315)41:6<1053: :AID-ANIE1053>3.0.CO;2-4

92. D. M. Quinn, Chem. Rev., 1987, 87, 955-979. https://doi.org/10.1021/cr00081a005

93. P. Taylor, Z. Radić, Annu. Rev. Pharmacol. Toxicol., 1994, 34, 281-320.

https://doi.org/10.1146/annurev.pa.34.040194.001433

94. J. L. Sussman, M. Harel, F. Frolow, C. Oefner, A. Goldman, L. Toker, I. Silman, Science, 1991, 253, 872-879. https://doi.org/10.1126/science.1678899

95. M. Harel, I. Schalk, L. Ehret-Sabatier, F. Bouet, M. Goeldner, C. Hirth, P. H. Axelsen, I. Silman, J. L. Sussman, Proc. Natl. Acad. Sci. USA, 1993, 90, 9031-9035. https://doi.org/10.1073/pnas.90.19.9031

96. E. Albert, F. Phillip, In: Alzheimer Disease: From Molecular Biology to Therapy., R. Berker, E. Giacobini, Eds., Birkhauser: Boston, 1996, pp. 211-215.

97. Y.-P. Pang, P. Quiram, T. Jelacic, F. Hong, S. Brimijoin, J. Biol. Chem., 1996, 271, 23646-23649.

https://doi.org/10.1074/jbc.271.39.23646

98. P. R. Carlier, D.-M. Du, Y.-F. Han, J. Liu, E. Perola, I. D. Williams, Y.-P. Pang, Angew. Chem., Int. Ed., 2000, 39, 1775-1777. 
https://doi.org/10.1002/(SICI)1521-3773(20000515)39: 10<1775::AID-ANIE1775>3.0.CO;2-Q

99. Z. Radić, P. Taylor, J. Biol. Chem., 2001, 276, 4622-4633. https://doi.org/10.1074/jbc.M006855200

100. P. R. Carlier, Y.-F. Han, E. S.-H. Chow, C. P.-L. Li, H.-S. Wang, T. X. Lieu, H. S. Wong, Y.-P. Pang, Bioorg. Med. Chem., 1999, 7, 351-357. https://doi.org/10.1016/S0968-0896(98)00213-2

101. Z. Shen, J. J. Thomas, C. Averbuj, K. M. Broo, M. Engelhard, J. E. Crowell, M. G. Finn, G. Siuzdak, Anal. Chem., 2001, 73, 612-619. https://doi.org/10.1021/ac000746f

102. Z. Radić, R. Duran, D. C. Vellom, Y. Li, C. Cervenansky, P. Taylor, J. Biol. Chem., 1994, 269, 11233-11239.

103. M. Harel, D. M. Quinn, H. K. Nair, I. Silman, J. L. Sussman, J. Am. Chem. Soc., 1996, 118, 2340-2346. https://doi.org/10.1021/ja952232h

104. P. Camps, B. Cusack, W. D. Mallender, R. El Achab, J. Morral, D. Muñoz-Torrero, T. L. Rosenberry, Mol. Pharmacol., 2000, 57, 409-417.

105. R. Manetsch, A. Krasiñski, Z. Radić, J. Raushel, P. Taylor, K. B. Sharpless, H. C. Kolb, J. Am. Chem. Soc., 2004, 126, 12809-12818. https://doi.org/10.1021/ja046382g

106. A. Krasiñski, Z. Radić, R. Manetsch, J. Raushel, P. Taylor, K. B. Sharpless, H.C. Kolb, J. Am. Chem. Soc., 2005, 127, 6686-6692. https://doi.org/10.1021/ja043031t

107. T. C. Marrs, Pharmacol. Ther., 1993, 58, 51-66. https://doi.org/10.1016/0163-7258(93)90066-M

108. N. Yanagisawa, H. Morita, T. Nakajima, J. Neurol. Sci., 2006, 249, 76-85. https://doi.org/10.1016/j.jns.2006.06.007

109. M. Jokanović, M.P. Stojiljković, Eur. J. Pharmacol., 2006, 553, 10-17. https://doi.org/10.1016/j.ejphar.2006.09.054

110. F. Worek, P. Eyer, N. Aurbek, L. Szinicz, H. Thiermann, Toxicol. Appl. Pharmacol., 2007, 219, 226-234. https://doi.org/10.1016/j.taap.2006.10.001

111. P. Taylor, In: Goodman and Gilman's the Pharmacological Basis of Therapeutics, 13th ed., L.L. Brunton, B.A. Chabner, B.C. Knollman, Eds., McGraw-Hill: New York, 2011, pp. 239-254.

112. R. K. Sit, Z. Radić, V. Gerardi, L. Zhang, E. Garcia, M. Katalinić, G. Amitai, Z. Kovarik, V. V. Fokin, K. B. Sharpless, P. Taylor, J. Biol. Chem., 2011, 286, 19422-19430. https://doi.org/10.1074/jbc.M111.230656

113. Z. Kovarik, N. Maček, R.K. Sit, Z. Radić, V. V. Fokin, K. B. Sharpless, P. Taylor, Chem. Biol. Interact., 2013, 203, 7780. https://doi.org/10.1016/j.cbi.2012.08.019

114. O. Lockridge, C. F. Bartels, T. A. Vaughan, C. K. Wong, S. E. Norton, L. L. Johnson, J. Biol. Chem., 1987, 262, 549- 557.

115. M.-M. Mesulam, A. Guillozet, P. Shaw, A. Levey, E.G. Duysen, O. Lockridge, Neuroscience, 2002, 110, 627-639. https://doi.org/10.1016/S0306-4522(01)00613-3

116. A. Tunek, L. A. Svensson, Drug Metab. Dispos., 1988, 16, 759-764.

117. E. Reiner, Z. Radić, In: Cholinesterases and Cholinesterase Inhibitors, 1st ed., E. Giacobini, Ed., Martin Dunitz Ltd.: London, 2000, pp. 103-121.
118. B. M. Liederer, R. T. Borchardt, J. Pharm. Sci., 2006, 95, 1177-1195. https://doi.org/10.1002/jps.20542

119. Z. Kovarik, Z. Radić, H.A. Berman, V. Simeon-Rudolf, E. Reiner, P. Taylor, Biochem. J., 2003, 373, 33-40. https://doi.org/10.1042/bj20021862

120. A. Bosak, I. Gazić, V. Vinković, Z. Kovarik, Arch. Biochem. Biophys., 2008, 471, 72-76.

https://doi.org/10.1016/j.abb.2007.12.007

121. M. Katalinić, G. Rusak, J. Domaćinović Barović, G. Šinko, D. Jelić, R. Antolović, Z. Kovarik, Eur. J. Med. Chem., 2010, 45, 186-192. https://doi.org/10.1016/j.ejmech.2009.09.041

122. G. Šinko, Z. Kovarik, E. Reiner, V. Simeon-Rudolf, J. Stojan, Biochemie, 2011, 93, 1797-1807. https://doi.org/10.1016/j.biochi.2011.06.023

123. A. Bosak, I. Gazić Smilović, G. Šinko, V. Vinković, Z. Kovarik, J. Med. Chem., 2012, 55, 6716-6723. https://doi.org/10.1021/jm300289k

124. N. P. Grimster, B. Stump, J. R. Fotsing, T. Weide, T. T. Talley, J. G. Yamauchi, Á. Nemecz, C. Kim, K.-Y. Ho, K. B. Sharpless, P. Taylor, V. V. Fokin, J. Am. Chem. Soc., 2012, 134, 6732-6740. https://doi.org/10.1021/ja3001858

125. J. P. Changeux, S. J. Edelstein, Nicotinic Acetylcholine Receptors: From Molecular Biology to Cognition, 1st ed., Johns Hopkins University Press: New York, 2005.

126. J. P. Changeux, A. Taly, Trends Mol. Med., 2008, 14, 93102. https://doi.org/10.1016/j.molmed.2008.01.001

127. J. P. Changeux, Nat. Rev. Neurosci., 2010, 11, 389-401. https://doi.org/10.1038/nrn2849

128. X. Xiu, N. L. Puskar, J. A. P. Shanata, H. A. Lester, D. A. Dougherty, Nature, 2009, 458, 534-537. https://doi.org/10.1038/nature07768

129. A. T. Poulin-Kerstien, P. B. Dervan, J. Am. Chem. Soc., 2003, 125, 15811-15821. https://doi.org/10.1021/ja030494a

130. S. Imoto, T. Hirohama, F. Nagatsugi, Bioorg. Med. Chem. Lett., 2008, 18, 5660-5663. https://doi.org/10.1016/j.bmcl.2008.08.074

131. B. E. Edelson, P. B. Dervan, Curr. Opin. Struct. Biol., 2003, 13, 284-299.

https://doi.org/10.1016/S0959-440X(03)00081-2

132. J. W. Trauger, E. E. Baird, P. B. Dervan, J. Am. Chem. Soc., 1998, 120, 3534-3535.

https://doi.org/10.1021/ja9800378

133. M. Faria, C. Giovannangeli, J. Gene Med., 2001, 3, 299310. https://doi.org/10.1002/jgm.192

134. I. Kers, P. B. Dervan, Bioorg. Med. Chem., 2002, 10, 33393349. https://doi.org/10.1016/S0968-0896(02)00221-3

135. P. Weyermann, P. B. Dervan, J. Am. Chem. Soc., 2002, 124, 6872-6878. https://doi.org/10.1021/ja020258k

136. J. M. Belitsky, S. J. Leslie, P. S. Arora, T. A. Beerman, P. B. Dervan, Bioorg. Med. Chem., 2002, 10, 3313-3318. https://doi.org/10.1016/S0968-0896(02)00204-3

137. R. K. Bruick, P. E. Dawson, S. B. H. Kent, N. Usman, G. F. Joyce, Chem. Biol., 1996, 3, 49-56. https://doi.org/10.1016/S1074-5521(96)90084-8 
138. J. L. Czlapinski, T. L. Sheppard, J. Am. Chem. Soc., 2001, 123, 8618-8619. https://doi.org/10.1021/ja0162212

139. D. Summerer, A. Marx, Angew. Chem., Int. Ed., 2002, 41, 89-90. https://doi.org/10.1002/1521-3773(20020104)41:1<89: :AID-ANIE89>3.0.CO;2-G

140. Z. J. Gartner, R. Grubina, C. T. Calderone, D. R. Liu, Angew. Chem., Int. Ed., 2003, 42, 1370-1375. https://doi.org/10.1002/anie.200390351

141. R. N. Warrener, D. N. Butler, D. Margetić, F. M. Pfeffer, R. A. Russell, Tetrahedron Lett., 2001, 41, 4671-4675. https://doi.org/10.1016/S0040-4039(00)00685-7

142. M. Di Antonio, G. Biffi, A. Mariani, E.-A. Raiber, R. Rodriguez, S. Balasubramanian, Angew. Chem., Int. Ed., 2012, 51, 11073-11078. https://doi.org/10.1002/anie.201206281

143. A. Ambrus, D. Chen, J. Dai, T. Bialis, R. A. Jones, D. Yang, Nucleic Acids Res., 2006, 34, 2723-2735. https://doi.org/10.1093/nar/gkl348

144. I. Glassford, C. N. Teijaro, S. S. Daher, A. Weil, M. C. Small, S. K. Redhu, D. J. Colussi, M. A. Jacobson, W. E. Childers, B. Buttaro, A. W. Nicholson, A. D. MacKerell, B. S. Cooperman, R. B. Andrade, J. Am. Chem. Soc., 2016, 138, 3136-3144. https://doi.org/10.1021/jacs.5b13008

145. N. Willand, M. Desroses, P. Toto, B. Dirié, Z. Lens, V. Villeret, P. Rucktooa, C. Locht, A. Baulard, B. Deprez, ACS Chem. Biol., 2010, 5, 1007-1013. https://doi.org/10.1021/cb100177g

146. H. D. Agnew, R. D. Rohde, S. V. Millward, A. Nag, W.-S. Yeo, J. H. Hein, S. M. Pitram, A. T. Ahad, A. M. Burns, J. R. Krom, V. V. Fokin, K. B. Sharpless, J. R. Heath, Angew. Chem., Int. Ed., 2009, 48, 4944-4948. https://doi.org/10.1002/anie.200900488

147. K. S. Lam, S. E. Salmon, E. M. Hersh, V. J. Hruby, W. M. Kazmierski, R. J. Knappt, Nature, 1991, 354, 82-84. https://doi.org/10.1038/354082a0

148. D. G. Udugamasooriya, S. P. Dineen, R. A. Brekken, T. Kodadek, J. Am. Chem. Soc., 2008, 130, 5744-5752. https://doi.org/10.1021/ja711193x

149. G. Liu, K. S. Lam, In: Combinatorial Chemistry-A Practical Approach Series., H. Fenniri, Ed., Oxford University Press: New York, 2000, pp. 43-44.

150. S. W. Millward, R. K. Henning, G. A. Kwong, S. Pitram, H. D. Agnew, K. M. Deyle, A. Nag, J. Hein, S. S. Lee, J. Lim, J. A. Pfeilsticker, K. B. Sharpless, J. R. Heath, J. Am. Chem. Soc., 2011, 133, 18280-18288. https://doi.org/10.1021/ja2064389

151. I. Vivanco, C. L. Sawyers, Nat. Rev. Cancer, 2002, 2, 489501. https://doi.org/10.1038/nrc839

152. C. M. Niemeyer, M. Adler, R. Wacker, Trends Biotechnol., 2005, 23, 208-216. https://doi.org/10.1016/j.tibtech.2005.02.006

153. S. L. Posy, M. A. Hermsmeier, W. Vaccaro, K.-H. Ott, G. Todderud, J. S. Lippy, G. L. Trainor, D. A. Loughney, S. R. Johnson, J. Med. Chem., 2011, 54, 54-66. https://doi.org/10.1021/jm101195a

154. J. F. Schildbach, D. J. Panka, D. R. Parks, G. C. Jager, J. Novotny, L. A. Herzenberg, M. Mudgett-Hunter, R. E. Bruccoleri, E. Haber, M. N. Margolies, J. Biol. Chem., 1991, 266, 4640-4647.

155. L. Jen-Jacobson, Biopolymers, 1997, 44, 153-180. https://doi.org/10.1002/(SICI)1097-0282(1997)44:2<153: :AID-BIP4>3.0.CO;2-U

156. J. T. Nguyen, M. Porter, M. Amoui, W. T. Miller, R. N. Zuckermann, W. A. Lim, Chem. Biol., 2000, 7, 463-473. https://doi.org/10.1016/S1074-5521(00)00130-7

157. C. Peruzzotti, S. Borrelli, M. Ventura, R. Pantano, G. Fumagalli, M. S. Christodoulou, D. Monticelli, M. Luzzani, A. C. Fallacara, C. Tintori, M. Botta, D. Passarella, ACS Med. Chem. Lett., 2013, 4, 274-277. https://doi.org/10.1021/ml300394w

158. M. Mondal, N. Radeva, H. Köster, A. Park, C. Potamitis, M. Zervou, G. Klebe, A. K. H. Hirsch, Angew. Chem., Int. Ed., 2014, 53, 3259-3263.

https://doi.org/10.1002/anie.201309682

\section{Povzetek}

Sodobno odkrivanje zdravil v glavnem temelji na de novo sintezah velikega števila spojin z različnimi kemijskimi funkcionalnimi skupinami. Čeprav je kombinatorialna kemija omogočila pripravo velikih knjižnic spojin iz različnih gradnikov, še vedno ostaja težava identifikacije spojin vodnic. Odkritje dinamičnih metod kombinatorialne kemije predstavlja korak naprej, saj pri sami sintezi visoko afinitetnih produktov vključuje biološke makromolekularne tarče (receptorje). Glavni preboj predstavlja sintezna metoda pri kateri se gradniki ireverzibilno povežejo le ob prisotnosti receptorja. Predstavljamo različne pristope v kombinatorialni kemiji, ki temeljijo na prisotnosti receptorjev. Pri Huisgenovi cikloadiciji (1,3-dipolarna cikloadicija azidov $\mathrm{z}$ alkini) nastanejo stabilni 1,2,3-triazoli; pogosto z zelo visokimi afinitetami do receptorja, ki lahko dosežejo celo femtomolarno območje, kot prikazuje primer z inhibitorji acetilholinesteraze. Huisgenovo cikloadicijo lahko uporabimo tudi pri različnih drugih receptorjih: acetilholinesterazi; proteinih, ki vežejo acetilholin; karboanhidrazi-II, serin/treonin-proteinski kinazi in pri vezavi na mali žleb DNA. 